\title{
FISCAL CONSOLIDATION IN THE EU-28: MULTIYEAR VERSUS COLD-SHOWER EPISODES
}

\author{
Olgica Clavaski* and Emilija Beker Pucar \\ Faculty of Economics in Subotica, University of Novi Sad, The Republic of Serbia
}

\begin{abstract}
In the aftermath of the global recession, the need for fiscal consolidation in order to reduce budget deficits and the public debt has intensified, but with the aim to make the measures applied not affect the further slowdown of the economic activity in the European Union (EU) economies. In this paper, the episodes of the fiscal consolidation in the period from 1990 to 2015 in the $28 \mathrm{EU}$ economies are analyzed, differentiating the multiyear episodes against the one-year (i.e. cold shower) episodes and their effects before and after the global recession. The episodes of the fiscal consolidation that result in successful (a reduction in the cyclically-adjusted primary budget deficit) and expansionary effects (the GDP growth) are identified, thus empirically confirming the existence of non-Keynesian effects. The stated affirms the idea that the achievement of fiscal sustainability by using austerity measures does not necessarily imply contractions in economies and that the development of a fiscal architecture in the EU by establishing complementarity between the national and supranational fiscal rules is of extraordinary importance in the post-crisis period.
\end{abstract}

Keywords: fiscal consolidation, EU economies, fiscal rules, non-Keynesian effects

\section{JEL Classification: H30, H62, F15}

\section{INTRODUCTION}

In the aftermath of the global economic and financial recession, the need for fiscal consolidation in order to reduce the budget deficit and the public debt has intensified, but with the aim to make the measures applied not affect the further slowdown of the economic activity in the European Union (EU) economies. Therefore, the analysis of the fiscal

* Correspondence to: O. Glavaski, Faculty of Economics in Subotica, University of Novi Sad, Segedinski put 9-11, 24000 Subotica, The Republic of Serbia; e-mail: olgicai@ef.uns.ac.rs adjustment channels and the implemented episodes of the fiscal consolidation in the period before and after the recession can provide us with the knowledge of the effects of the undertaken measures, and, in a broader context, the effects of the success of the discretionary fiscal policy.

A fiscal consolidation episode is a period of fiscal adjustment, which can be directed towards a reduction in public spending and/or tax growth, with the aim of reducing the cyclically-adjusted primary deficit and public debt. The specifics of each episode of fiscal consolidation are determined by: the 
duration (multiyear episodes versus a cold shower), the composition of public spending/public revenues, the effects (expansionary versus contractionary effects, and successful versus unsuccessful effects), and the period of application (recession versus expansion). The heterogeneity of the fiscal adjustment measures in the EU stems from a lack of a single fiscal policy at the EU level. The pre-global recession contracts, the Maastricht Treaty (1992) and the Stability and Growth Pact (1997), left room for a potential fiscal irresponsibility in the EU economies. The two key rules of the Maastricht Treaty reading that a budget deficit must not exceed 3\% of the GDP and that the public debt must not exceed a total of $60 \%$ of the GDP were insufficient to guarantee fiscal sustainability. After the spillover effects of the global recession on the fiscal sphere in the EU, a new fiscal framework (Two-Pack, Six-Pack, Fiscal Compact 2012, European Stability Mechanism 2012) were defined with clear preventive and corrective arms, as well as the intention of introducing the EU fiscal rules in the national legislations.

The aforementioned contracts and the circumstances that further intensified the importance of the study of fiscal consolidation in the EU also refer to a loss of the national monetary policies as the instruments for macroeconomic stabilization in the monetary union (for more information about the monetary phases and the monetary union, see the paper by (Beker Pucar \& Glavaski, 2019). Despite the flexibility of the national fiscal policies, the implemented fiscal policy measures could not absorb the asymmetric shocks generated in the crisis conditions, although the episodes of fiscal consolidation clearly pointed to the fight for the achievement of fiscal sustainability by implementing austerity measures.

In this regard, this paper analyzes the episodes of the fiscal consolidation in the period from 1990 to 2015, in the context of the differentiation between the multiyear episodes the one-year (i.e. cold-shower) fiscal consolidation episodes and their effects in the 28 EU economies before and after the global recession.

This research study is aimed at identifying whether the cold showers or multiyear episodes of the fiscal consolidation were more successful in the reduction in the cyclically-adjusted primary budget deficit, and whether they had any expansionary or contractionary effects before and after the global recession. Although the fiscal consolidation in the pre-crisis period with the lessons of the post-crisis period is relatively often analyzed in the literature (Barrios, Langedijk \& Pench, 2010), this paper fills the gap in the literature by making a comparison of the implemented episodes and their effects in the periods before and after the global recession, sublimating the overall measures in the fiscal sphere in the aftermath of the global recession.

The basic research hypothesis states:

H1: There are successful and expansionary effects of the cold-shower and multiyear episodes of the fiscal consolidation before and after the global recession.

Namely, this assumption refers to the existence of non-Keynesian effects in the EU economies, ensuring recommendations for policymakers that not all austerity measures result in contractionary effects. Additionally, the following hypothesis that is:

H2: There are differences in the duration, structure and effect of the fiscal consolidation before and after the global recession.

The hypotheses are tested by using scientific-research instrumentation, based on the methods of analysis and synthesis, descriptive statistical analysis and the method of comparison.

The paper structure is defined as follows. The first part shows a reference discourse in relation to the time, way and effects of the fiscal consolidation episodes. In the second part, the theoretical framework of the fiscal consolidation channels on the demand and supply sides is presented. The third and fourth parts are focused on the specifics of the EU fiscal framework - in the third part, the basic fiscal rules in the EU are sublimated, while in the fourth part, the empirically tested effects of the fiscal consolidation episodes before and after the recession are shown. The last part of the paper synthesizes the basic conclusions. 


\section{LITERATURE REVIEW}

Fiscal consolidation implies a measure of the fiscal adjustment aimed at reducing budget deficits and the public debt through a reduction in public spending or tax growth, taking into account the cost of the slowing-down economic activity slowing down. It raises the question of whether a reduction in public spending or tax raising is a better strategy for stabilizing the budget deficit and avoiding a recession. In the period after the global recession, the economies were faced with the need for more drastic budget deficit and public debt cuts; however, there was a fear that fiscal consolidation might cause a new recession. The majority of the EU economies finally implemented fiscal consolidation; yet, according to the authors A. Alesina, O. Barbiero, C. Favero, F. Giavazzi and M. Paradisi (2015a), if they did the best thing is still not quite clear.

The basic fiscal consolidation issues in the theoretical and empirical literature can be summarized as follows:

- duration of fiscal consolidation,

- manner of fiscal consolidation, and

- effects of fiscal consolidation.

The answer to the first question is endogenous. Namely, when a crisis happens, it automatically requires measures to overcome the recession. So, fiscal consolidation is usually introduced during a recession and gains a procyclical character. Empirically speaking, a sharp rise in the public debt and the budget deficit is easier to treat than accumulated and prolongated problems in public finance. In this context, A. Alesina (2010) showed that certain fiscal consolidation episodes, especially those conducted on the side of public spending cuts, had not caused the recession. Namely, the author relativizes the necessity for the existence of a trade-off between the stabilization function and fiscal consolidation. G. Corsetti, K. Kuester, A. Meier and C. Muller (2010) explain that a reduction in public spending increases expansionary effects due to the anticipation of lower inflationary pressure and a stable long-term interest rate. By using the ex-post analysis of fiscal consolidation, A. Alesina and S. Ardagna (2010) discovered that a reduction in public spending aimed at reducing the budget deficit had not caused the recession, but quite the opposite, it had caused expansion. These results refer to the existence of non-Keynesian effects, i.e. a reduction in public spending aimed at reducing a budget deficit may have positive effects in the context of economic growth through specific transmission mechanisms. In the following papers, the authors claim that there are non-Keynesian effects: F. Giavazzi and M. Pagano (1990); A. Alesina and R. Perotti (1998); A. Alesina and S. Ardanga (1998; 2010); on the other hand, there are those who believe that non-Keynesian effects are very unusual: J. Guajardo, D. Leigh and A. Pescatori (2011); W. Yang, J. Fidrmuc and S. Ghosh (2015).

In connection with the second question, A. Alesina, G. Azzalini, O. Favero, C. Giavezzi and A. Miano (2017) demonstrate that, if fiscal consolidation is based on the permanent growth of tax rates, it is more expensive in terms of output losses in the short time compared to the fiscal consolidation based on a permanent reduction in public spending. It was also confirmed in the works of J. von Hagen, A. Hughes Hallett and R. Straush (2002); R. Maroto and C. MulasGranados (2007); European Commission (2007); M. Kumar, D. Leigh and A. Plekhanov (2007).

A possible explanation was given by the European Commission (2007): a reduction in public spending is most commonly related to an increase in efficiency in the public sector and may send signals to financial markets for long-term fiscal sustainability. Additionally, although there is a consensus in the literature in relation to higher costs in the case of fiscal consolidation based on the permanent growth of tax rates, the issue of the composition of public spending and public revenues still remains important. The available research studies dedicated to this topic (Alesina, Favero \& Giavazzi, 2015a) are oriented towards the separation of public spending into the two components:

- consumption and investment - they include all public spending from which the government expects a positive yield, either financially or in terms of growing welfare (the consumption 
of public goods, salaries in the public sector, contributions to insurance, expenses for education, healthcare, road reconstruction, railways, hospitals, commercial and industrial buildings); and

- transfers - they include all public spending from which government does not expect direct economic benefits (social protection, social benefits in cash or in nature, scholarships, subsidies).

On the other hand, public revenues may be separated into the following components:

- direct taxes - they include all public revenues having distortions in terms of work preference (income, profits, capital gains, the property tax (Tanasić, 2019);

- indirect taxes - they include all public revenues not having distorting effects (value added tax, tax turnover, taxes, registration, natural monopoly profit tax).

Empirical studies (using the example of the OECD countries in a study by A. Alesina et al (2015b) indicate that there is no significant difference in the effects of direct and indirect taxes on economic growth and a reduction in deficits and the public debt, whereas transfers also have similar (contractionary) effects. Only consumption and investments usually have no contractionary effects, i.e. there are non-Keynesian effects in the short term - a reduction in public spending in the part of consumption and investment does not necessarily imply a reduction in economic growth in the short run. Finally, the question of how to implement fiscal consolidation relates to a decision on whether to implement fiscal consolidation as a oneyear measure (i.e. a cold shower) or gradually, in terms of multiyear episodes. A. Alesina et al (2015b) showed that non-Keynesian effects had been identified in multiyear episodes, rather than in "stop-and-go" (i.e. cold-shower) changes in public spending and taxes.

The subject matter of the third question relates to the successful/unsuccessful and expansionary/ contractionary effects of fiscal consolidation. Success is determined by the effects on a budget deficit and the public debt, whereas the term expansionary is determined by effects on the output. According to a paper by A. Alesina and S. Ardanga (2010), the fiscal adjustment period is the period in which the growth of the cyclically-adjusted primary budget is at least $1.5 \%$ of the GDP. Fiscal consolidation is considered as successful if the cumulative reduction of the public debt in the GDP exceeds $4.5 \%$ of the GDP three years after the fiscal consolidation has been imposed. In the opposite case, fiscal consolidation is unsuccessful. Fiscal consolidation is considered to be expanded if the average economic growth during the implementation period and in a period of two years after that exceeds $75 \%$ of economic growth in all fiscal consolidation episodes. In the opposite case, such fiscal consolidation is contractionary.

In this paper, the results of the cold-shower and multiyear episodes of fiscal consolidation in the context of their success (non-success) and expansionary (contractionary) effects in the period before and after the global recession are analyzed.

\section{THEORETICAL FRAMEWORK: FISCAL CONSOLIDATION CHANNELS}

With the aim of further analyzing the mechanisms through which fiscal consolidation episodes demonstrate expansionary/contractionary effects, and how successful they are in the process of reducing a cyclically-adjusted budget deficit, the channels of the influence on the demand side and on the supply side are presented. The expansionary effects of fiscal consolidation can be seen on both sides of the channel (Alesina \& Ardagna, 2010). On the demand side, fiscal consolidation could be expansionary if agents believe that fiscal tightening is the result of the major changes in the fiscal policy, eliminating the need for undertaking new measures in the future. Tax growth or a reduction in public spending is perceived as a less bad scenario from the point of view of the risk of an even-deeper fiscal tension. Consumers believe that this scenario incurs lesser costs, and that, indirectly, their available income is higher (if the measures of stronger fiscal tightening must be applied, those costs would be a reality for consumers, which they are not 
in these circumstances). Higher income implies more private consumption, which is determined by the existence of "liquidity constrained" consumers or a lack of them.

Whether consumers will behave in accordance with the Keynesian recession expectations during fiscal consolidation or there will be non-Keynesian effects depends on the debt level (Sutherland, 1997). Fiscal consolidation leads to the expectations of lower future taxes; however, if the levels of the public debt are relatively low, consumers do not expect significantly lower taxes in the future, thus creating common Keynesian effects (reducing current consumption, inducing negative effects on the output). In the case of the high levels of the public debt and higher cuts in public spending, agents act in accordance with non-Keynesian effects: believing that they will pay less in taxes in the future, they increase their current spending, thus generating growth.

The second channel is in relation to the expectations cherished for the interest rate. If agents believe that fiscal consolidation is credible and affects a reduction in the public debt, it is possible that a reduction in the interest rate on state bonds will also take place. Private demand may grow if the real interest rate is reduced for the private sector, as a consequence of a reduction in the real interest rate on state bonds. Reducing the real interest rate on state bonds may affect the growth of bond values, which ultimately increases the financial welfare of agents, which on its part may cause a boom in consumption and investments. Therefore, in some cases, expectations for changing the regime of the fiscal policy may positively affect welfare through a reduction in long-term interest rates. The credibility of the economic policy designers is also the key moment, or the third channel.

On the supply side, the effects of fiscal consolidation pertain to the labor market and the effects of tax hikes and/or a reduction in public spending on individual work supply. If there is a decrease in public spending, it means a reduction in the number of those employed in the public sector who have a difficulty in finding a job in the private sector. Those who remain employed in the public sector are faced with reduced salaries.
Both effects may positively affect the private sector, i.e. larger workforce supply allows for a reduction in the salaries of employees in the private sector, and the growth of investments, profits, and competitiveness. The second channel, through tax hikes, (in particular income tax) has consequences for a higher burden for employers and lesser net wages for employees. Those effects might suppress profits and investments, as well as competitiveness, and they may also have overall negative effects on welfare.

In relation to the composition of fiscal consolidation (public spending on consumption, investment and transfers, and taxes on direct and indirect taxes) some of them might have effects on a recession/expansion. A reduction in public spending and investment will have a different influence on economic growth, depending on productivity in the public sector. A reduction in public spending and investment has an influence on consumers' expectations related to lower taxes in the future, changing the relative price ratio of public goods to private goods, given the assumption that public and private goods are subsidies. The expectations that public goods will be relatively cheaper generate higher consumption and economic growth. A reduction in transfers reduces households' income, reducing spending as well. The growth of direct and indirect taxes according to the effects on economic growth only differs in distortive effects, i.e. indirect taxes do not have distortive effects, because they do not change the marginal rate of substitution.

The described channels are considered to be important enough to explain the expansionary or contractionary effects of fiscal consolidation. A. Alesina, S. Ardagna, R. Perotti and F. Schiantarelli (2002) empirically demonstrated that the size of the fiscal shock due to the fiscal consolidation was large enough to cause positive effects in terms of private consumption and negative effects due to the investment tax growth. Which effects are larger in a concrete economy depending on the composition of fiscal consolidation leads to expansionary or contractionary effects on economic growth. The race between the channels of expectation and the labor market channel is constantly occurrent in fiscal consolidation, in which the labor market channel more often wins (Ardanga, 2004). 


\section{FISCAL RULES IN THE EU}

Fiscal rules at the supranational EU level were built gradually and became more rigid over time, especially so in the period after the global recession. With the aim of fulfilling the fiscal rules and securing fiscal sustainability, fiscal consolidation became an acute topic in many economies.

The pre-global recession contracts, the Maastricht Contract and the Stability and Growth Pact, left room for a potential fiscal irresponsibility in the EU economies. The two key rules of the Maastricht Treaty's fiscal sphere (that the budget deficit must not exceed $3 \%$ of the GDP, and the public debt must not exceed $60 \%$ of the GDP) were powerless to guarantee fiscal sustainability. Hence, the Stability and Growth Pact of 1997 (together with the reform of 2005) had a predominantly preventive character, respecting the principles of democracy and flexibility, retaining fiscal policies within the sovereign frames. Given the need for collective discipline, the Stability and Growth Pact retained its frames at the level of coordination by using the two types of arms. The preventive arm involved the strengthening of supervision over the budgetary positions and the coordination of the economic policies, whereas the corrective arm implied the defining of the proceedings in the case of an excessive deficit. The escalation of the global recession and the violation of the reformed Stability and Growth Pact conditioned the introduction of the new mechanisms of governance, with the focus on the financial stabilization mechanisms in the countries with fiscal problems. The mechanisms would only be initiated according to the strict rules and if the Eurozone were endangered, and they would represent a wider framework of action, substantially including the fiscal sphere. Firstly, the European Semester was established in 2010 as a part of the EU fiscal policy coordination mechanism. Secondly, the European financial stability mechanism (EFSM) and the European Financial Stability Fund (EFSF) were established. Moreover, in 2012, the European Stability Mechanism (ESM) was established, defined by the international agreement between the Eurozone members, with a total capacity of 700 billion euros. The ESM was aimed at providing the economies with preventive assistance, adding loans, buying Euro-member bonds on the primary and secondary markets, and providing loans to the governments. The rescue mechanisms (bail-out) was used to support the economies with difficulties in accession to international capital markets or those that had completely lost access to them (such as Greece, Portugal, Ireland, Cyprus, and Spain). The ESM finally replaced the previously defined EFSM and EFSF programs and the new Eurozone Recovery Program started being exclusively implemented through the ESM.

In the context of the fiscal rules, a tougher fiscal framework is defined through the six-pack and two-pack reforms and the Fiscal Compact (2012). According to the Fiscal Compact, the EU Member States are obligated to maintain a budget balance or a budget surplus. The limit is prescribed by a structural deficit, which must not exceed $0.5 \%$ of the GDP, or $1 \%$ of the GDP if the public debt is below $60 \%$ of the GDP. If a country does not sign the Fiscal Compact, it cannot receive assistance based on the ESM. Additionally, it defined the initiative that the limit for a structural deficit of $0.5 \%$ of the GDP had to be introduced in national legislation. (Bova, Kinda, Muthoora \& Toscani, 2015) Most countries have done that (although some with a delay, like Belgium and Greece), while the others have imposed these provisions at the legislative level, not at the constitutional level, as was recommended.

The existing legislation has improved the monitoring of the EU Member States' budgetary policies, but the strengthening of the fiscal capacity and further steps in the convergence of the Eurozone's and EU countries' fiscal policies still remain important issues. There are new proposals for the development of the legislative framework (European Commission, 2018), led by the European Investment Stabilization Function (EISF). The EISF is defined as a part of the Financial Perspective 2021-2027, with the aim of establishing macroeconomic stabilization and a strong response to asymmetric shocks and preventing crisis spillover effects. Therefore, the new framework for the fiscal rules (Schaechter, 2012) is directed towards the stabilization function, as well as the greater convergence of the fiscal policies of the EU countries. 


\section{COLD-SHOWER VERSUS MULTIYEAR EPISODES IN THE EU BEFORE THE GLOBAL RECESSION}

Taking into account the existing architecture of the fiscal rules in the EU and the theoretical framework for the channel which comes to the effects of fiscal consolidation, the empirical analyses of the fiscal consolidation episodes in the period before and after the global recession in the EU economies is presented.

Based on the length of fiscal consolidation, fiscal consolidation exists when the budget deficit is reduced from 1 to $2 \%$ of the GDP in a year (a cold shower). The explanation for this definition lies in the fact that changing the budget deficit on such a scale cannot be due to the common movement in the economy, but this extraordinary result is automatically connected with the fiscal policy measures. In particular, in the paper by A. Alesina and S. Ardanga (2009), the fiscal consolidation period of one year is considered to be that period in which the growth of the cyclicallyadjusted primary budget balance is at least $1.5 \%$ of the GDP. Fiscal consolidation is considered to be successful if there has been a cumulative reduction in the public debt share in the GDP for an amount greater than $4.5 \%$ of the GDP three years after the introduction of fiscal consolidation. The effects of fiscal consolidation are considered as expansionary if average economic growth in the implementation period and two years after that period is greater than $75 \%$ of economic growth during all the episodes of the fiscal consolidation. The two criteria are interconnected, because the positive effects of fiscal consolidation on growth mean a greater likelihood that the effects of fiscal consolidation will be expanded and consequently successful. So, a cold shower implies relatively big changes in the fiscal area made in a short period of time, unlike multiyear changes, which are smaller, but made within a longer period of time. Therefore, fiscal consolidation episodes can be defined as long-term changes in the fiscal policy management measured by using the cyclically-adjusted budget balance. Specifically (Alesina \& Ardanga, 2015), a multiyear episode of fiscal consolidation is defined as:

- a period of two years, in which the total improves the position of cyclically-adjusted primary deficits by $2 \%$ of the GDP (and there is an improvement in both years in particular);

- a period of 3 years, in which the total improves the position of the cyclically-adjusted primary deficit by $3 \%$ of the GDP (and there is an improvement in all three years in particular).

When multiyear episodes are concerned, fiscal consolidation is considered as successful if the share of the public debt in the GDP is smaller in the period of two years after the fiscal consolidation episode in relation to its value in the last year of that episode. Fiscal consolidation is expansionary if the GDP growth during the fiscal adjustment period exceeds that of the period preceding that episode.

A cold shower is recorded in the largest number of the EU economies in the analyzed period before the global recession (1990-2007). A comparative overview of the fiscal consolidations is shown in Table 1, using the alternative methods:

- ex-post, based on the changes in the cyclicallyadjusted primary deficit, processed in M. Larch and A. Turrini (2008) and in the paper by A. Alesina and S. Ardanga (2015), and

- narrative, the method applied in P. Devries, J. Guajardo, D. Leigh and A. Pescaroti (2011).

Both methods recognize a cold shower in certain years, except in the case of Bulgaria (which, therefore, is not shown in the table), while the relevant data for the entire period are not available for Greece. The dynamics of the implementation of the fiscal consolidation episodes and their success differ in the analyzed time period. In the first decade, i.e. from 1990 to 2000, as many as a hundred cold-shower episodes were implemented in the EU. Their success was higher in the period from 1995 to 2000 in comparison with the period from 1990 to 1995 as a consequence of the defined fiscal framework at the EU level and the convergence process within the EMU framework. The period after the global recession (2000-2007) was characterized by the fiscal consolidation fatigue that reflected in a reduced number of cold showers in the EU countries (36 episodes), whose success was questionable in the largest number of cases. This 
Table 1 Cold-shower vs. multiyear episodes in the EU economies before the global recession

\begin{tabular}{|c|c|c|c|c|c|c|c|c|c|c|c|c|c|c|c|c|c|c|c|}
\hline & \multicolumn{18}{|c|}{ Cold showers } & \multirow{2}{*}{$\begin{array}{r}\text { Multiyear } \\
\text { episodes }\end{array}$} \\
\hline & 욤 & হু & ๙ू & ๙ু & ন & ๙ू & ஜू & ๙ & ळ & হ & 옴 & $\overline{\grave{d}}$ & $\begin{array}{l}\text { 응 } \\
\text { O }\end{array}$ & $\stackrel{m}{\stackrel{一}{\circ}}$ & $\begin{array}{l}\text { ঠ } \\
\text { ঃ }\end{array}$ & ํㅗㅇ & $\begin{array}{l}\text { ○ } \\
\text { ○ }\end{array}$ & 옴 & \\
\hline AT & & & & & & & + & + & & & & + & + & & & & & & 96-97 \\
\hline $\mathrm{BE}$ & + & & & + & + & + & + & + & + & + & + & + & & & & & + & & $96-98$ \\
\hline $\mathrm{CY}$ & & & & & & & & & & & + & & & & + & + & & & \\
\hline$C Z$ & & & & & & & & & & & & & & & + & & & & \\
\hline \multirow[t]{2}{*}{ DE } & & + & + & + & + & + & + & + & + & + & + & & & + & + & + & + & + & $\begin{array}{l}92-94 \\
96-00\end{array}$ \\
\hline & & & & & & & & & & & & & & & & & & & $03-07$ \\
\hline DK & & & & & & + & & & & & & & & & + & + & & & $03-05$ \\
\hline $\mathrm{EE}$ & & & & & & & & & & & + & & & + & & & & & \\
\hline ES & \multirow[t]{2}{*}{+} & & + & + & + & + & + & + & & & & & & & & & & & $94-97$ \\
\hline $\mathrm{FR}$ & & & + & + & + & + & + & + & + & & & & & & & & & & $\begin{array}{l}94-01 \\
04-06\end{array}$ \\
\hline $\mathrm{FI}$ & + & + & & & + & + & + & + & + & + & + & & & & & & & & $\begin{array}{l}93-94 \\
96-98\end{array}$ \\
\hline GB & & & & & + & + & + & + & + & + & + & & & & & & & & \\
\hline HU & & & & & & & & & & + & & & & + & & & & & \\
\hline $\mathrm{IT}$ & + & + & + & + & + & + & + & + & + & & & & & & + & + & + & + & $\begin{array}{l}95-97 \\
06-07\end{array}$ \\
\hline $\mathrm{IE}$ & & & & & & & + & + & + & & & & & & + & & & & $\begin{array}{l}91-94 \\
96-98\end{array}$ \\
\hline LV & & & & & & & + & & & & + & & & & & & & & $03-05$ \\
\hline $\mathrm{LT}$ & & & & & & & & & + & + & & & & & & & & & \\
\hline LU & & & & + & & & & + & & & & & & & & & & & $94-96$ \\
\hline MT & & & & & & & & & & + & & & & & + & + & & & $00-02$ \\
\hline $\mathrm{NL}$ & & + & + & + & & & + & + & + & + & + & & & & + & + & & & $\begin{array}{l}96-00 \\
04-05\end{array}$ \\
\hline PL & & & & & & & & & & & & & & & & + & & & \\
\hline PT & & & + & & + & + & & & & & + & & + & + & & + & + & + & $\begin{array}{l}94-95 \\
02-03 \\
06-07\end{array}$ \\
\hline RO & & & & & & & & + & + & + & & & & & & & & & \\
\hline SE & & & & + & + & + & + & + & + & & & & & & + & + & & & $\begin{array}{l}93-98 \\
03-05\end{array}$ \\
\hline SI & & & & & & & & & & & & & + & & & & & & \\
\hline SK & & & & & & & & & + & & & + & & + & & & & & \\
\hline UK & & & & & & & + & + & + & & + & & & & & & & & $94-00$ \\
\hline & 음 & হু & ๙ั & ๙ু & ন & ڤั & ڤ̆ & 응 & 吕 & হু & 음 & $\bar{\delta}$ & 응 & m & ষ্ণ & ํㅗㅇ & $\begin{array}{l}\text { О } \\
\text { ○ }\end{array}$ & 응 & \\
\hline
\end{tabular}

+ Indicates the annual and multiyear fiscal consolidations established in the papers by Larch and Turrini, 2008; Alesina and Ardanga, 2010; Devries, Guajardo, Leigh and Pescaroti, 2011

Source: Authors 
could be explained by a slowdown in the economic activity and the effects of the fiscal consolidation were under the impact of repetitious negative growth rates.

According to the analysis of all the years in which the fiscal consolidation was being conducted in the EU economies until the global recession, cold showers turned out to be more frequently implemented than fiscal consolidation multiyear episodes. In $70 \%$ of the cold showers, the GDP growth was recorded by over $1.5 \%$ of the GDP, while in the emerging EU economies, a total of $30 \%$ of the cold-shower episodes resulted in a growth exceeding 3\% of the GDP (Larch \& Turrini, 2008). Namely, in the pre-accession and accession periods, the new EU economies had significant and favorable results of the implemented fiscal consolidation measures.

In addition to the identification of the fiscal consolidation multiyear episodes, it is also of interest to determine their success in the context of reducing the cyclically-adjusted budget deficit (namely, the expansionary against contractionary effects of fiscal consolidation). Although there is a hypothesis in economic theory in terms of the expectation of contractionary effects in the event of a reduction in public spending or an increase in taxes in the implementation of fiscal consolidation, A. Alessina and S. Ardanga (2015) demonstrated that fiscal consolidation was more frequently unsuccessful than with contractionary effects. So, the more frequent problem is the inability to minimize a cyclicallyadjusted budget deficit than contractionary effects (Figure 1).

Figure 1 shows that only two multiyear episodes of the fiscal consolidation (in Germany (1996-2000) and in Portugal (2002-2003)) may be characterized as unsuccessful and contractionary. All the other identified episodes resulted in expansionary effects, thus empirically affirming the existence of nonKeynesian effects, confirming the research hypothesis. In addition, the results of the empirical analysis suggest that the fiscal consolidation measures based on a reduction in public spending are more often connected with expansionary effects, and with success in reducing the public debt and budget deficits, in comparison to a tax reduction. On the other hand, the most successful multiyear fiscal consolidation is that conducted in Sweden in the period from 1993 to 1998, when the fiscal consolidation was reduced by the cyclically-adjusted budget deficit by $14 \%$ than it was

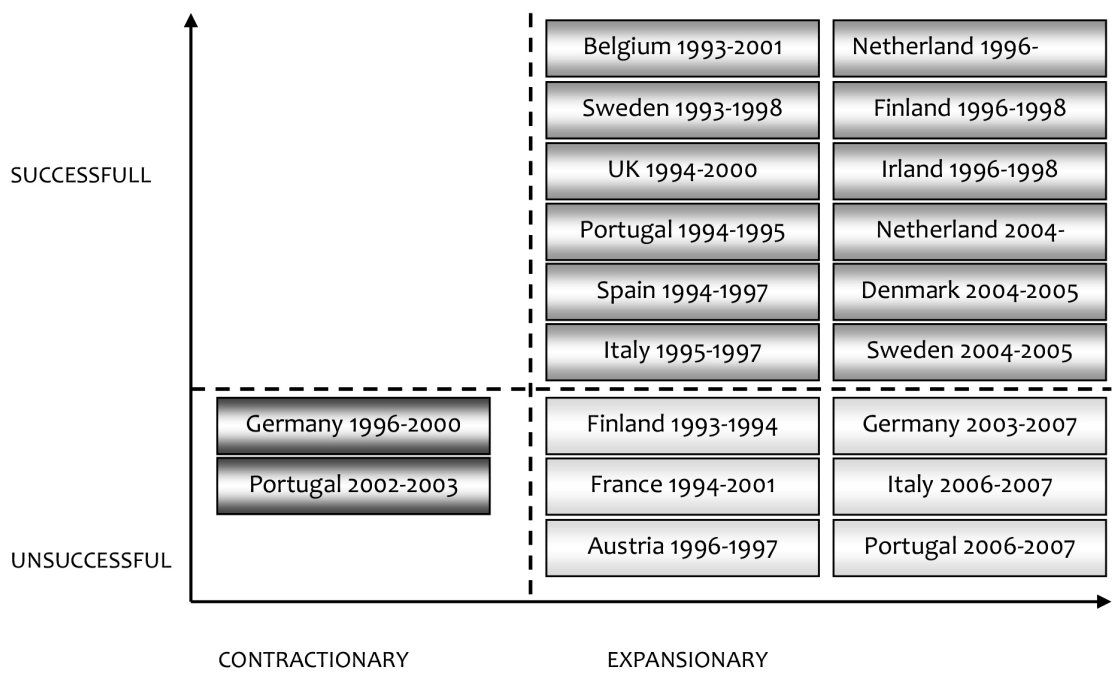

Figure 1 The (un)successful and expansionary/contractionary episodes of the fiscal consolidation 
the case in the UK in the period from 1994 to 2000, with the reduction of $11 \%$, and in the Netherlands for the period from 1996 to 2000, with a reduction in the cyclically- adjusted budget deficit by $8.8 \%$.

\section{FISCAL CONSOLIDATION AFTER THE GLOBAL RECESSION}

After the global recession, the EU economies began to implement complex reforms in the fiscal policy field, including fiscal consolidations, the excessive deficit procedure (EDP) and the use of support programs. By entering the EDP procedure, the European Commission assumes the monitoring of public finance. Great Britain entered the EDP in 2008, whereas Spain, Greece, Ireland, France, Germany, Italy, Portugal, the Netherlands, Belgium and Austria entered it in 2009. However, the most endangered countries were the peripheral economics with already weak public finance, whose problems had intensified during the global recession (the share of the public debt in the GDP was 106\% in Italy in 2008, whereas in Greece, that share reached 100\%). The countries implemented support programs aimed at reducing budget deficits and the public debt, and also at strengthening the banking sector and ensuring economic growth. Finally, the idea was to regain investor confidence. Obtaining financial assistance is determined by the size of the fiscal crisis of the economy and potential dangers to the Eurozone, which implies that governments have to sign a Memorandum of Understanding (MoU) and the Fiscal Compact in order to ensure the consolidation of public finance. A total of five different recovery programs were defined to be implemented, depending on the Troika's decision.

The EFSM was financed by the European Commission's borrowing on international financial markets, where the EU's budget was a guarantee. Table 2 shows the implemented financial stabilization programs. In the period from 2011 to 2014, a total of 22.5 billion euros were provided to Ireland, and 24.3 billion euros to Portugal, while in 2015, a short-term loan of 7.16 billion euros was granted to Greece. From the EFSF program in the period from 2011 to 2013, a total of 17.7 billion euros was distributed, with the repayment period from 2029 to 2042, whereas in the period from 2011 to 2014, a total of 26 billion euros was distributed to Portugal, with the repayment period from 2025 to 2040, while Greece received 141.8 billion euros from the EFSF in the period from 2012 to 2015 (the source of the data is the ESM). An overview of the implemented programs under the umbrella of the EFSF, EFSM and ESM is shown in the following table. In addition to these countries, indirect aid was also received by Italy, whose bonds were purchased by the European Central Bank in the amount of 102.8 billion euros. In a similar fashion, the ECB bought 14.2 billion euros in the case of Ireland, while 33.9 billion euros in the case of Greece, 44.3 billion euros in the case of Spain, and 22.8 billion euros in the case of Portugal. It turns out that emergency support programs contributed to the recovery of the economy and the prevention of the deterioration of a deep recession into a depression.

Table 2 shows the depth of the budget deficit before and after the implementation of the financial stabilization programs. However, the improvement is not only a consequence of significant financial assistance, but also the completed fiscal consolidation in the EU economies. The permanent episodes of fiscal consolidation were implemented in the majority of the EU economies and they were especially necessary in the fragile countries with the high budget deficits and public debt prior to the recession period - mostly the EU peripheral countries (Janković, 2019). However, the necessity for fiscal consolidation was manifested in the old EU members as well, so the first multiyear episode of the fiscal consolidation after the global recession lasted from 2010 to 2013, and the second lasted in the period from 2014 until 2015 (in Austria, Denmark, Germany, Ireland, Italy, Portugal, Spain, Great Britain). On the other hand, Finland, the Netherlands and Sweden were implementing the multiyear fiscal consolidation from 2010 to 2015. Therefore, the hypothesis that there are differences in the duration, structure and effects of the fiscal consolidations before and after the global recession is confirmed. 
Table 2 The implemented financial stabilization programs

\begin{tabular}{|c|c|c|c|c|c|}
\hline & $\begin{array}{l}\text { Source } \\
\text { of fina- } \\
\text { ncing }\end{array}$ & Duration & Amount & $\begin{array}{l}\text { Budget } \\
\text { before }\end{array}$ & $\begin{array}{l}\text { Budget } \\
\text { after }\end{array}$ \\
\hline Greece & $\begin{array}{l}\text { EFSF, } \\
\text { EFSM, } \\
\text { ESM, } \\
\text { MMF }\end{array}$ & $2011-2019$ & $\begin{array}{l}256 \\
\text { billion } \\
\text { euros }\end{array}$ & $\begin{array}{l}-15.1 \% \\
\text { of the } \\
\text { GDP in } \\
2009\end{array}$ & $\begin{array}{l}1.1 \% \\
\text { of the } \\
\text { GDP in } \\
2018\end{array}$ \\
\hline Portugal & $\begin{array}{l}\text { EFSF, } \\
\text { EFSM, } \\
\text { MMF }\end{array}$ & $2011-2014$ & $\begin{array}{l}78 \\
\text { billion } \\
\text { euros }\end{array}$ & $\begin{array}{l}-11.2 \% \\
\text { of the } \\
\text { GDP in } \\
2010\end{array}$ & $\begin{array}{l}0.5 \% \\
\text { of the } \\
\text { GDP in } \\
2018\end{array}$ \\
\hline Ireland & $\begin{array}{l}\text { EFSF, } \\
\text { EFSM }\end{array}$ & $\begin{array}{l}2010- \\
2013\end{array}$ & $\begin{array}{l}85 \\
\text { billion } \\
\text { euros }\end{array}$ & $\begin{array}{l}-32.1 \% \\
\text { of the } \\
\text { GDP in } \\
2010\end{array}$ & $\begin{array}{l}0 \% \text { of } \\
\text { the } \\
\text { GDP in } \\
2018\end{array}$ \\
\hline Spain & ESM & $\begin{array}{l}2012- \\
2013\end{array}$ & $\begin{array}{l}41.3 \\
\text { billion } \\
\text { euros }\end{array}$ & $\begin{array}{l}-11 \% \\
\text { of the } \\
\text { GDP in } \\
2009\end{array}$ & $\begin{array}{l}-2.5 \% \\
\text { of the } \\
\text { GDP in } \\
2018\end{array}$ \\
\hline Cyprus & $\begin{array}{l}\text { ESM, } \\
\text { MMF }\end{array}$ & $\begin{array}{l}2012- \\
2016\end{array}$ & $\begin{array}{l}10 \\
\text { billion } \\
\text { euros }\end{array}$ & $\begin{array}{l}-9 \% \text { of } \\
\text { the } \\
\text { GDP in } \\
2014\end{array}$ & $\begin{array}{l}-4.8 \% \\
\text { of the } \\
\text { GDP in } \\
2018\end{array}$ \\
\hline
\end{tabular}

Source: Authors

The effects of the implemented fiscal consolidation after the global recession reflected through a reduction in the value of the flow variable (the cyclically-adjusted budget deficit); however, the fiscal consolidations were less successful in the reduction in the stock variable (the accumulated level of the public debt). Namely, according to B. Pierluigi and D. Sondermann (2018), the macroeconomic imbalances in the flow variables in the first decade of EMU were adjusted to a significant extent, whereas the macroeconomic imbalances in stock variables were detained. Therefore, newer governance mechanisms, strengthening the fiscal framework by establishing stronger and more innovative fiscal rules, and their implementation into national legislation have become exceptionally important (Debrun, Moulin, Turrini, Ayuso-i-Casals \& Kumar, 2008).

\section{CONCLUSION}

The global recession highlighted all the imperfections of the unfinished construction of the European Union. With the unique monetary policy, the heterogeneous fiscal policy did not prove to be able to absorb the asymmetric shocks generated in crisis conditions despite the flexibility of the national fiscal policies. Therefore, the effects of the fiscal consolidations in the $28 \mathrm{EU}$ economies in the period before and after the recession (1990-2007 and 2010-2015, respectively) were compared, taking into account the length of the fiscal consolidation (cold-shower vs. multiyear episodes), and the effects of the applied fiscal consolidations (success/a lack of success in a reduction/increase in the cyclically-adjusted budget deficit and expansionary/ contractionary effects in the context of an increase/ decrease in the GDP).

The dynamics of the implementation of the fiscal consolidation episodes and their success differ in the analyzed period of time. The research hypothesis was confirmed by pointing out the fact that there are successful and expansionary effects of the cold showers and gradual episodes of the fiscal consolidation before and after the global recession. In the pre-crisis period, the number of the implemented one-year episodes (the so-called cold showers) was higher than in the post-crisis period, when the multiyear fiscal consolidations were mainly implemented. Overall, the success of the cold showers was recorded in $70 \%$ of the implemented fiscal consolidations, particularly in the emerging EU economies. In connection with the effects of the fiscal consolidation, the data suggest that only two multiyear episodes (those in Germany (1996-2000) and Portugal (2002-2003) might be characterized as unsuccessful and with contractionary effects. All the other identified episodes resulted in expansionary effects, thus empirically confirming the existence of non-Keynesian effects. The implications of the empirical analysis that must be taken into consideration by policymakers are indicative of the fact that fiscal consolidations based on a reduction in public spending are more often connected with expansionary effects, and with success in reducing the public debt and budget deficits, in comparison with a reduction in taxes. 
After the global recession, the EU economies began to implement complex reforms in the fiscal policy field, which did not only include fiscal consolidation in the economies with excessive budget deficits. Some countries entered the EDP procedure, and some were a part of the implemented support programs in the context of the European Stability mechanisms. The permanent episodes of the fiscal consolidation were conducted in the largest number of the EU economies starting in the year 2010 and the same proved to be necessary in the fragile countries with the high budget deficits and public debt before the recession. Thus, strengthening the fiscal framework and the complementarity between the supranational and national fiscal arrangements in the post-crisis period are of extraordinary importance.

The effects of the implemented fiscal consolidation after the global recession reflected through a reduction in the cyclically-adjusted primary budget deficit (the flow variable); however, the question still remains how much those measures were successful in reducing the accumulated public debt (the stock variable). Therefore, future research should be directed towards the panel data multi-cointegration analysis that would capture the connection between the flow and stock variables in the analysis of the fiscal consolidation effects in the EU economies.

\section{REFERENCES}

Alesina, A., \& Perotti, R. (1998). Fiscal adjustments in OECD countries: Composition and macroeconomic effects. IMF Staff Papers, 44(2), 210-248. doi.org/10.2307/3867543

Alesina, A., \& Ardanga, S. (1998). Tales of fiscal adjustment. Economic Policy, 13(27), 487-545. doi.org/10.1111/14680327.00039

Alesina, A., Ardagna, S., Perotti, R., \& Schiantarelli, F. (2002). Fiscal policy, profits, and investment. American Economic Review, 92(3), 571-589. doi:10.1257/00028280260136255

Alesina, A. (2010, April). Fiscal adjustments: Lessons from recent history. Paper presented at the ECOFIN meeting in Madrid.
Alesina, A., \& Ardagna, S. (2010). Large changes in fiscal policy: Taxes versus spending. Tax policy and the economy, 24, 35-68. doi.org/10.1086/649828

Alesina, A., Barbiero, O., Favero, C., Giavazzi, F., \& Paradisi, M. (2015a). Austerity in 2009-2013. Economic Policy, 30(83), 383-437. doi:10.1093/epolic/eiv006

Alesina, A., Favero, C., \& Giavazzi, F. (2015a). The Output Effects of Fiscal Consolidation Plans. Journal of International Economics, 96(S1), S19-S42. doi.org/10.1016/j. jinteco.2014.11.003

Alesina, A., Azzalini, G., Favero, C., Giavezzi, F., \& Miano, A. (2017). Is it the "How" or the "When" that Matters in Fiscal Adjustments? IMF Economic Review, 66(1), 144-188. doi:10.1057/s41308-017-0047-z

Ardagna, S. (2004). Fiscal Stabilizations: When do they work and why. European Economic Review, 48(5), 1047-1074. doi:10.1016/j.euroecorev.2003.09.010

Barrios, S., Langedijk, S., \& Pench, L. R. (2010). EU fiscal consolidation after crisis: Lessons from past experiences. European Economy - Economic Papers 2008-2015, No 418. doi:10.2765/42879 Beker Pucar, E., \& Glavaski, O. (2019). Monetary stages and frameworks of emerging EU members. Economic Horizons, 21(1), 29-42. doi:10.5937/ ekonhor1901029B

Bova, E., Kinda, T., Muthoora, P., \& Toscani, F. (2015). Fiscal rules at a glance. Working Paper 12/273, International Monetary Fund.

Corsetti, G., Kuester, K., Meier, A., \& Muller, G. J. (2010). Debt consolidation and fiscal stabilization of deep recessions. American Economic Review, 100(2), 41-45. doi:10.1257/ aer.100.2.41

Debrun, X., Moulin, L., Turrini, A., Ayuso-i-Casals, J., \& Kumar, M. S. (2008). Tied to the Mast? The Role of National Fiscal Rules in the European Union. Economic Policy, 23(54), 297-362.

Devries, P., Guajardo, J., Leigh, D., \& Pescaroti, A. (2011). A new action-based dataset on fiscal consolidation. Working Paper WP/11/128, International Monetary Fund.

European Commission. (2007). Public finance in EMU 2007. European Commission.

European Commission. (2018). Proposal for a regulation of the European Parliament and of the Council on the establishment of a European Investment Stabilisation Function. Brussels. 
Giavazzi, F., \& Pagano, M. (1990). Can severe fiscal contractions be expansionary? Tales of two small European countries. NBER Macroeconomic Annual 1990, 5, 75-122. doi:10.2307/3585133

Guajardo, J., Leigh, D., \& Pescatori, A. (2011). Expansionary austerity: New international evidence. Working Paper 11/158, International Monetary Fund.

Janković, M. (2019). Impact of financial structure on economic growth: Example of Serbia, Croatia and Slovenia. Anali Ekonomskog Fakulteta u Subotici, 55(42), 147-162. doi:10.5937/ AnEkSub1942147J

Kumar, M., Leigh, D., \& Plekhanov, A. (2007). Fiscal adjustments: Determinants and macroeconomic consequences. Working Paper No. 07/178, International Monetary Fund.

Larch, M., \& Turrini, A. (2008). Received wisdom and beyond: Lessons from fiscal consolidation in the EU. National Institute Economic Review 217(320), European Commission. doi:10.2139/ssrn.1284378

Maroto, R., \& Mulas-Granados, C. (2007). What makes fiscal policy sustainable? A survival analysis of fiscal consolidation in Europe. Public Choice, 134(3), 147-161. doi:10.1007/s11127-007-9211-8
Pierluigi, B., \& Sondermann, D. (2018). Macroeconomic imbalances in the euro area: Where do we stand? Occasional Paper Series No 211, European Central Bank.

Schaechter, A., Kinda, T., Budina, N., \& Weber, A. (2012). Fiscal rules in response to the crisis - toward the "nextgeneration" rules. A New Dataset. Working Paper, 12/187, International Monetary Fund.

Sutherland, A. (1997). Fiscal crises and aggregate demand: can high public debt reverse the effects of fiscal policy? Journal of Public Economics, 65(2), 147-162. doi.org/10.1016/S00472727(97)00027-3

Tanasić, L. (2019). Comparative overview of transfer pricing tax regulation in the World. Anali Ekonomskog Fakulteta u Subotici, 55(42), 111-127. doi:10.5937/AnEkSub1942111T

Von Hagen, J., Hughes Hallet, A., \& Straush, R. (2002). Budgetary institutions for sustainable fiscal policies. In M. Buti, J. Von Hagen, and C. M. Mongay (Eds.). The Behaviuor of Fiscal Authorities: Stabilization, Growth and Institutions (pp. 94-110). London, UK: Palgrave Macmillan.

Yang, W., Fidrmuc, J., \& Ghosh, S. (2015). Macroeconomic effects of fiscal adjustment: A tale of two approaches. Journal of International Money and Finance, 57, 31-60. doi. org/10.1016/j.jimonfin.2015.05.003

Received on $16^{\text {th }}$ February 2019, after revision, accepted for publication on $13^{\text {th }}$ April 2020

Published online on $24^{\text {th }}$ April 2020

Olgica Glavaski is an assistant professor at Faculty of Economics in Subotica, University of Novi Sad. She obtained her PhD thesis at the Faculty of Economics in Belgrade in the scientific field of Economics. The key area of her research interest are economic policies, with a special focus on the fiscal policy and the sustainability of public spending.

Emilija Beker Pucar is an associate professor at the Faculty of Economics in Subotica, University of Novi Sad where she obtained her PhD thesis in the scientific field of General Economic Theory and Policy. The key area of her research interest are economic policies, with a special focus on the monetary policy and exchangerate regimes. 


\title{
FISKALNA KONSOLIDACIJA U EU-28: VIŠEGODIŠNJE EPIZODE VERSUS HLADAN TUŠ
}

\author{
Olgica Glavaški* i Emilija Beker Pucar \\ Ekonomski fakultet u Subotici, Univerzitet u Novom Sadu
}

U periodu nakon Globalne recesije, intenzivirano je pitanje potreba za fiskalnim konsolidacijama sa ciljem smanjenja budžetskog deficita i javnog duga, a da mere koje se primenjuju ne utiču dodatno na usporavanje privredne aktivnosti u ekonomijama Evropske Unije (EU). Predmet istraživanja u ovom radu su epizode fiskalnih konsolidacija u periodu 1990-2015, u 28 ekonomija EU, u kontekstu diferencijacije višegodišnjih nasuprot jednogodišnjih (hladan tuš) epizoda i njihovih efekata, pre i nakon Globalne recesije. Identifikovane su epizode fiskalnih konsolidacija koje rezultiraju uspešnim (smanjenje ciklično prilagođenog primarnog budžetskog deficita) i ekspanzivnim efektima (rast BDP-a), čime je empirijski potvrđeno postojanje ne-Kejnzijanskih efekata. Navedeno afirmiše ideju da borba za uspostavljanje fiskalne održivosti merama austerije ne znači nužno kontrakcije u ekonomijama, kao i da je razvoj fiskalne arhitekture u EU, uspostavljanjem komplementarnosti između supranacionalnih i nacionalnih fiskalnih aranžmana u post-kriznom periodu, od izuzetne važnosti.

Ključne reči: fiskalna konsolidacija, ekonomije EU, fiskalna pravila, ne-Kejnzijanski efekti

JEL Classification: H30, H62, F15

\section{UVOD}

U periodu nakon Globalne ekonomske i finansijske recesije, intenzivirano je pitanje potreba za fiskalnim konsolidacijama, sa ciljem smanjenja budžetskog deficita i javnog duga, a da mere koje se primenjuju ne utiču dodatno na usporavanje privredne aktivnosti ekonomija Evropske Unije (EU). S tim u vezi, analiza kanala fiskalnog prilagođavanja i implementiranih epizoda fiskalnih konsolidacija, u periodu pre i

* Korespondencija: O. Glavaški, Ekonomski fakultet u Subotici, Univerzitet u Novom Sadu, Segedinski put 9-11, 24000

Subotica, Republika Srbija; e-mail: olgicai@ef.uns.ac.rs nakon recesije, može pružiti saznanja o efektima sprovedenih mera i u širem kontekstu o uspešnosti diskrecione fiskalne politike.

Epizoda fiskalne konsolidacije je period fiskalnog prilagođavanja, koji može biti usmeren na redukciju javne potrošnje i(ili) rast poreza, sa ciljem smanjenja ciklično prilagođenog primarnog budžetskog deficita, a indirektno i na smanjenje javnog duga. Specifičnosti svake epizode fiskalne konsolidacije određene su dužinom trajanja (višegodišnje gradualne epizode naspram hladnog tuša), kompozicijom javne potrošnje/javnih prihoda, efektima (ekspanzivni naspram kontrakcioni i uspešni naspram neuspešni), 
ali i periodom primene (recesija nasuprot ekspanziji). Heterogenost mera fiskalnog prilagođavanja $\mathrm{u}$ EU proizlazi iz nepostojanja jedinstvene fiskalne politike na nivou EU. Ugovori iz perioda pre Globalne recesije, Ugovor iz Mastrihta (1992) i Pakt za stabilnost i rast (1997), i dalje su ostavljali prostor za potencijalnu fiskalnu neodgovornost $\mathrm{u}$ ekonomijama EU. Dva ključna pravila $u$ vezi sa javnim finansijama iz Mastrihtskog ugovora, da budžetski deficit ne sme preći 3\% BDP-a, a javni dug 60\% BDP-a, pokazali su se nemoćnim da zagarantuju fiskalnu održivost. Nakon prelivanja efekata Globalne recesije na fiskalnu sferu u EU, definisan je i oštriji fiskalni okvir (two-pack, six-pack, Fiskalni sporazum 2012, Evropski stabilizacioni mehanizam 2012), sa jasnim preventivnim, ali i kaznenim delovanjem, kao i intencijom uvođenja supranacionalnih pravila $\mathrm{u}$ nacionalno zakonodavstvo.

Navedeni ugovori i okolnosti, koje dodatno intenziviraju važnost proučavanja fiskalnih konsolidacija u EU, odnose se na gubljenje nacionalnih monetarnih politika kao instrumenata za makroekonomsku stabilizaciju u monetarnoj uniji (Beker Pucar \& Glavaski, 2019). Uprkos fleksibilnosti nacionalnih fiskalnih politika, uz definisan okvir fiskalne politike $\mathrm{u} E U$, sprovedene mere se nisu pokazale sposobnim da apsorbuju asimetrične šokove koji su se u recesionim uslovima generisali, premda su epizode fiskalnih konsolidacija, nedvosmisleno, ukazivale na borbu za uspostavljanjem fiskalne održivosti merama austerije.

$\mathrm{S}$ tim $\mathrm{u}$ vezi, predmet istraživanja $\mathrm{u}$ ovom radu su epizode fiskalnih konsolidacija, u periodu 19902015, u 28 ekonomija EU, u kontekstu diferencijacije višegodišnih nasuprot izdašnijih jednogodišnjih (hladan tuš) epizoda, pre i nakon Globalne recesije i njihovi efekti.

Cilj istraživanja je usmeren ka identifikaciji da li su hladni tuševi, ili višegodišnje epizode fiskalnih konsolidacija bili uspešniji u smanjenju ciklično prilagođenog primarnog budžetskog deficita i da li su imali ekspanzivne ili kontrakcione efekte pre i nakon Globalne recesije. Iako je u literaturi relativno često predmet analize fiskalna konsolidacija u predrecesionom periodu, uz izvođenje lekcija za post- recesioni period (Barrios, Langedijk \& Pench, 2010), u ovom radu se jaz $\mathrm{u}$ literaturi ispunjava komparacijom realno implementiranih epizoda i njihovih efekata $\mathrm{u}$ periodu pre, ali i nakon Globalne recesije, sublimiranjem sveobuhvatnih mera $u$ fiskalnoj sferi $\mathrm{u}$ periodu nakon Globalne recesije.

Osnovna istraživačka hipoteza u radu je:

H1: Postoje uspešni i ekspanzivni efekti hladnog tuša i graduelnih epizoda fiskalne konsolidacije pre i nakon Globalne recesije.

Naime, na ovaj način se polazi od pretpostavke o postojanju ne-Kejnzijanskih efekata u ekonomijama EU, obezbeđujući preporuke kreatorima ekonomske politike da ne rezultiraju sve mere austerije kontrakcionim efektima. Dodatno, testira se hipoteza:

H2: Postoje razlike $u$ dužini trajanja, strukturi i efektima fiskalnih konsolidacija pre i nakon Globalne recesije.

U radu se primenjuje naučno-istraživački instrumentarijum zasnovan na metodi analize i sinteze, deskriptivnoj statističkoj analizi i metodi komparacije.

Struktura rada je definisana na sledeći način. U prvom delu je prikazan referentni diskurs na temu vremena, načina i efekata epizoda fiskalnih konsolidacija. U drugom delu je predstavljen teorijski okvir kanala putem kojih se ispoljavaju efekti sprovedenih mera na strani tražnje i ponude. Treći i četvrti deo fokusira specifičnosti fiskalnog okvira EU - u trećem delu su sublimirana osnovna fiskalna pravila u EU, dok su $\mathrm{u}$ četvrtom delu empirijski testirani efekti epizoda fiskalnih konsolidacija pre i nakon recesije. Poslednji deo rada sintetizuje osnovne zaključke.

\section{PREGLED LITERATURE}

Fiskalna konsolidacija podrazumeva meru fiskalnog prilagođavanja, sa ciljem smanjenja budžetskog deficita i javnog duga kroz smanjenje javne potrošnje ili rast poreza, uzimajući u obzir troškove usporavanja ekonomske aktivnosti. Postavlja se pitanje, koja je bolja strategija smanjenje javne potrošnje ili porast 
poreza kako bi se stabilizovao budžetski deficit i javni dug, a recesija izbegla? Nakon Globalne recesije, pogotovo, ekonomije su bile suočene sa potrebom za drastičnijim rezanjem budžetskog deficita i javnog duga, uz uvažavanje okolnosti da fiskalna konsolidacija može uzrokovati novu recesiju. Međutim, u post-recesionom periodu, većina ekonomija EU su sprovele mere fiskalne konsolidacije, ali da li su uradile najbolju stvar, uzimajući u obzir nalaze autora A. Alesina, O. Barbiero, C. Favero, F. Giavazzi i M. Paradisi (2015a); i dalje nije sasvim jasna.

Osnovna pitanja koja se tiču fiskalne konsolidacije, u teorijskoj i empirijskoj literaturi, mogu se svesti na sledeća:

- vreme sprovođenja fiskalne konsolidacije,

- način sprovođenja fiskalne konsolidacije, i

- efekti fiskalne konsolidacije.

Odgovor na pitanje vremena sprovođenja fiskalne konsolidacije je endogeno. Naime, kada se kriza desi, ona automatski iziskuje mere za izlazak iz krize, pa se fiskalno prilagođavanje najčešće uvodi tokom recesije, te dobija prociklični karakter. Iskustva pokazuju da se oštri porast javnog duga i budžetskog deficita lakše leči, nego akumulirani i prolongirani problemi u javnim finansijama. Ohrabrujućim se može smatrati i odgovor (Alesina, 2010), da postoje epizode fiskalne konsolidacije (pogotovo one sprovedene na strani smanjenja javne potrošnje), koje nisu prouzrokovale recesije. Naime, autor relativizira neophodnost postojanja trade-off-a između stabilizacione funkcije i fiskalne konsolidacije. G. Corsetti, K. Kuester, A. Meier i C. Muller (2010) objašnjavaju da smanjenje javne potrošnje povećava ekspanzivne efekte, usled anticipacije nižeg inflatornog pritiska i stabilne dugoročne kamatne stope. A. Alesina i S. Ardagna (2010) su, koristeći ex post analizu fiskalnih konsolidacija, otkrili da je smanjenje javne potrošnje sa ciljem smanjenja budžetskog deficita bilo ređe povezano sa recesijama, nego sa ekspanzijama. Ovi rezultati upućuju na postojanje ne-Kejnzijanskih efekata, odnosno, da smanjenje javne potrošnje sa ciljem umanjenja budžetskog deficita može imati pozitivne efekte $\mathrm{u}$ kontekstu privrednog rasta kroz specifične transmisione mehanizme. Radovi u kojima autori tvrde da postoje ne-Kejnzijanski efekti su F.
Giavazzi i M. Pagano (1990), A. Alesina i R. Perotti (1998), A. Alesina i S. Ardanga (1998, 2010), dok drugi smatraju da su ne-Kejnzijanski efekti veoma neuobičajeni (Guajardo, Leigh \& Pescatori, 2011; Yang, Fidrmuc \& Ghosh, 2015).

$\mathrm{U}$ vezi sa načinom sprovođenja fiskalne konsolidacije, A. Alesina, G. Azzalini, O. Favero, C. Giavezzi i A. Miano (2017) su pokazali da bez obzira na to da li fiskalna konsolidacija počinje $\mathrm{u}$ recesiji ili $\mathrm{u}$ ekspanziji, ukoliko je bazirana na permanentnom rastu poreskih stopa, skuplja je u smislu gubitaka $\mathrm{u}$ output-u u kratkom roku, u odnosu na fiskalnu konsolidaciju zasnovanu na permanentnom smanjenju javne potrošnje. Navedeno je potvrđeno i u radovima J. Von Hagen, A. Hughes Hallett i R. Straush (2002), R. Maroto i C. Mulas-Granados (2007), European Commission (2007), M. Kumar, D. Leigh i A. Plekhanov (2007).

Potencijalno objašnjenje dala je Evropska Komisija (2007): smanjenje javne potrošnje je, najčešće, povezano sa povećanjem efikasnosti $u$ javnom sektoru, te može poslati signale finansijskim tržištima $u$ vezi sa dugoročnom fiskalnom održivošću. Dodatno, iako je naučna javnost saglasna $u$ vezi sa većim troškovima u slučaju fiskalne konsolidacije zasnovane na permanentnom rastu poreskih stopa, postavlja se pitanje kompozicije javne potrošnje i javnih prihoda, čiji efekti se potencijalno mogu smatrati neKejnzijanskim. Raspoloživa istraživanja na ovu temu (Alesina, Favero \& Giavazzi, 2015b) idu u pravcu razdvajanja javne potrošnje na dve komponente:

- potrošnja i investicije - obuhvata sve javne izdatke od kojih država očekuje pozitivan prinos, finansijski ili u smislu porasta blagostanja ( $u$ šta je uključena potrošnja javnih dobara, plate $u$ javnom sektoru, doprinosi za osiguranje, izdaci za školstvo, zdravstvo, rekonstrukcija puteva, železnica, bolnica, komercijalnih i industrijskih građevina) i;

- transferi - obuhvataju sve javne izdatke od kojih država ne očekuje direktnu ekonomsku korist (socijalna zaštita, socijalni benefiti u gotovini ili u naturi, stipendije, subvencije). 
S druge strane, razdvajanje javnih prihoda odvija se putem:

- direktnih poreza - obuhvataju sve javne prihode koji mogu imati distorzivne efekte u smislu preferiranja dokolice $\mathrm{u}$ odnosu na rad (dohodak, profit, kapitalni dobici, porez na imovinu (Tanasić, 2019);

- indirektnih poreza - obuhvataju sve javne prihode koji nemaju distorzivne efekte (porez na dodatu vrednost, porez na promet, takse, registracije, porez na profit prirodnih monopola).

Empirijske studije (na primeru zemalja OECD-a, A. Alesina et al (2015b) ukazuju da ne postoji značajna razlika u efektima direktnih od indiretnih poreza na privredni rast i smanjenje deficita i javnog duga, dok transferi, takođe, imaju slične (kontrakcione) efekte. Različite efekte imaju samo potrošnja i investicije, koje najčešće nemaju kontrakcione efekte, odnosno, postoje ne-Kejnzijanski efekti u kratkom roku - smanjenje javne potrošnje u delu potrošnje i investicija, ne znači uvek smanjenje privrednog rasta u kratkom roku. Konačno, pitanje načina sprovođenja fiskalne konsolidacije, tiče se odluke da li se ona sprovodi kao jednogodišnja mera (cold shower, hladan tuš) ili gradualno, u smislu višegodišnjih mera. A. Alesina et al (2015b) pokazali su da su ne-Kejnzijanski efekti svojstveni uslovima u kojima se sprovode višegodišnje mere, pre nego stop and go (jednogodišnje) promene $\mathrm{u}$ javnoj potrošnji i porezima.

U vezi sa efektima fiskalne konsolidacije, oni mogu biti ispoljeni u formi uspešni/neuspešni i ekspanzivni/ kontrakcioni efekti. Uspešnost je određena efektima po budžetski deficit i javni dug, dok je ekspanzivnost determinisana efektima po output. Prema radu A. Alesina i S. Ardanga (2010), period fiskalne konsolidacije je onaj $\mathrm{u}$ kom je rast ciklično prilagođenog primarnog budžeta najmanje 1,5\% BDP-a. Fiskalna konsolidacija se smatra uspešnom ukoliko je kumulativno smanjenje javnog duga u BDP vrednost veća od 4,5\% BDP-a, tri godine nakon što su uvedene mere fiskalne konsolidacije. U obrnutom slučaju, fiskalna konsolidacija je neuspešna. Fiskalna konsolidacija se smatra ekspanzivnom ukoliko je prosečan privredni rast $\mathrm{u}$ periodu sprovođenja mera, i dve godine nakon toga, veći od vrednosti $75 \%$ ranga privrednog rasta tokom svih epizoda fiskalnog prilagođavanja. Ukoliko navedeno nije realizovano, fiskalna konsolidacija ima kontrakcione efekte.

U ovom radu će primenom komparativnog pristupa biti prikazani rezultati jednogodišnjih u odnosu na višegodišnje epizode fiskalne konsolidacije u kontekstu njihove uspešnosti (neuspešnosti) i ekspanzivnih (kontrakcionih) efekata u periodu pre i nakon Globalne recesije.

\section{TEORIJSKI OKVIR: KANALI FISKALNE KONSOLIDACIJE}

Sa ciljem detaljnije analize mehanizama putem kojih epizode fiskalne konsolidacije imaju ekspanzivne/ kontrakcione efekte i koliko su uspešne u procesu smanjenja ciklično prilagođenog budžetskog deficita, posebno su prezentovani kanali uticaja na strani tražnje i na strani ponude. Ekspanzivni efekti fiskalnog prilagođavanja mogu teći sa obe strane kanala (Alesina \& Ardagna, 2010). Sa strane tražnje, fiskalno prilagođavanje može biti ekspanzivno ukoliko pojedinci veruju da je fiskalno zatezanje rezultat velikih promena $\mathrm{u}$ vođenju fiskalne politike, koje se trenutno dešava, a koje eliminiše potrebu da $\mathrm{u}$ perspektivi budu preduzete nove mere fiskalnog zatezanja. Rast poreza ili smanjenje javne potrošnje, koje se percipira kao manje loš scenario, od onog da $\mathrm{u}$ perspektivi postoji opasnost da fiskalno zatezanje bude još dublje, može dovesti do pozitivnih efekata na blagostanje. Potrošači smatraju da ovaj scenario nosi sa sobom manje troškove, pa im je indirektno i raspoloživi dohodak veći (da se moraju primeniti mere jačeg fiskalnog zatezanja, ti troškovi bi bili realnost za potrošače, a ovako nisu). Veći dohodak znači veću privatnu potrošnju, koja je određena postojanjem ili nepostojanjem likvidnosnog ograničenja (liquidity constrained) potrošača.

Da li će se potrošači ponašati u skladu sa Kejnzijanskim recesionim očekivanjima prilikom 
fiskalne konsolidacije, ili će postojati ne-Kejnzijanski efekti, zavisi i od nivoa javnog duga (Sutherland, 1997). Fiskalno prilagođavanje dovodi do očekivanja nižih budućih poreza. Međutim, ukoliko su nivoi javnog duga relativno niski, potrošači ne očekuju značajno manje poreze $\mathrm{u}$ budućnosti stvarajući uobičajene Kejnzijanske efekte (smanjuju tekuću potrošnju, pa u kratkom roku dolazi do negativnih efekata na output). U slučaju visokih nivoa javnog duga i većih rezova $u$ javnoj potrošnji, pojedinci se ponašaju u skladu sa ne-Kejnzijanskim efektima, smatrajući da će u budućnosti plaćati manje poreze, povećavaju tekuću potrošnju, indukujući rast.

Drugi kanal koji se stvara je posledica očekivanja $\mathrm{u}$ vezi sa kamatnom stopom. Ukoliko u privatnom sektoru veruju da je fiskalno prilagođavanje kredibilno i da utiče na smanjenje javnog duga, moguće je da će doći do smanjenja kamatne stope na državne obveznice. Privatna tražnja može da poraste ukoliko se smanji realna kamatna stopa za privatni sektor, kao posledica smanjenja realne kamatne stope na državne obveznice. Smanjenje realne kamatne stope na državne obveznice može uticati na rast vrednosti obveznica, što na kraju povećava finansijsko blagostanje pojedinaca, čime može da izazove bum u potrošnji, odnosno, investicijama. Dakle, u nekim slučajevima, očekivanja u vezi sa promenom režima fiskalne politike može imati pozitivne efekte na blagostanje, kroz smanjenje dugoročnih kamatnih stopa. Kredibilitet kreatora ekonomske politike, takođe, predstavlja ključni momenat, odnosno, treći kanal.

Na strani ponude, efekti fiskalne konsolidacije se kreću kroz tržište rada i efekte koje porast poreza i (ili) smanjenje javne potrošnje imaju na individualnu ponudu rada. Ukoliko dolazi do smanjenja javne potrošnje, to znači smanjenje broja zaposlenih u javnom sektoru, koji teško pronalaze posao u privatnom sektoru. Oni koji su ostali zaposleni u javnom sektoru, suočavaju se sa smanjenim zaradama. Oba efekta mogu pozitivno uticati na privatni sektor, tako što veća ponuda radne snage omogućuje smanjenje zarada zaposlenima i u privatnom sektoru, te rast investicija, profita, kao i konkurentnosti. Drugi kanal, kroz povećanje poreza, konkretno poreza na dohodak, dolazi do većeg opterećenja za poslodavca i manje neto zarade za zaposlene. Navedeno može potisnuti profit i investicije, kao i konkurentnost i imati negativne efekte na blagostanje.

Ukoliko se posmatra kompozicija fiskalnog prilagođavanja, konkretno, javna potrošnja kroz potrošnju, investicije i transfere, a porezi kroz direktne i indirektne poreze, postoje kanali kojima ove izdvojene mere deluju na recesiju/ekspanziju. Smanjenje državne potrošnje i investicija će delovati $\mathrm{u}$ različitom stepenu na privredni rast, $\mathrm{u}$ zavisnosti od produktivnosti u javnom sektoru. Smanjenje javne potrošnje i investicija dovodi do toga da potrošači očekuju smanjenje poreza u budućnosti, pa se menja relativni odnos cena javnih $\mathrm{u}$ odnosu na privatna dobra, s obzirom na pretpostavku da su javna i privatna dobra supstituti. Očekivanja da će javna dobra biti relativno jeftinija, dovode do veće potrošnje i generisanja rasta. Smanjenje transfera umanjuje raspoloživi dohodak domaćinstava, umanjujući i potrošnju. Očekivanja u vezi sa budućim manjim porezima ostaju na snazi, kao i kod smanjenja potrošnje i investicija. Rast direktnih i indirektnih poreza se prema efektima na privredni rast razlikuje samo $\mathrm{u}$ distorzivnim efektima, tačnije, indirektni porezi nemaju distorzivne efekte, jer ne utiču na promenu marginalne stope supstitucije.

Opisani kanali smatraju se dovoljno važnim da mogu objasniti ekspanzivne ili kontrakcione efekte preduzetih mera fiskalne konsolidacije. A. Alesina, S. Ardagna, R. Perotti i F. Schiantarelli (2002) empirijski su pokazali da je veličina fiskalnog šoka usled fiskalne konsolidacije dovoljno velika da izazove pozitivne efekte $\mathrm{u}$ smislu privatne potrošnje, a negativne usled rasta poreza na investicije. Koji efekti su veći u konkretnoj ekonomiji, u zavisnosti od kompozicije mera, rezultiraju ekspanzivnim ili kontrakcionim efekata na privredni rast. Trka između kanala očekivanja i kanala tržišta radne snage se prilikom fiskalnog prilagođavanja konstantno odvija, u kojoj češće pobeđuje kanal tržišta radne snage (Ardanga, 2004). 


\section{FISKALNA PRAVILA U EU}

Fiskalna pravila, na supranacionalnom nivou EU, građena su gradualno, pa su tako postupno i pooštravana, a posebno $\mathrm{u}$ periodu nakon Globalne recesije. Sa ciljem ispunjenja sve strožijih fiskalnih pravila i obezbeđenja fiskalne održivosti, fiskalna konsolidacija postaje akutna tema $u$ mnogim ekonomijama.

Ugovori iz perioda pre Globalne recesije, Ugovor iz Mastrihta i Pakt za stabilnost i rast, ostavljali su i dalje prostor za potencijalnu fiskalnu neodgovornost u ekonomijama EU. Dva ključna pravila u fiskalnoj sferi iz Mastrihtskog ugovora, da budžetski deficit ne sme preći 3\% BDP-a, a javni dug 60\% BDP-a, pokazali su se nemoćnim da zagarantuju fiskalnu održivost. Stoga je Pakt za stabilnost i rast (zajedno sa reformom iz 2005), poštujući principe demokratičnosti, ali i fleksibilnosti, zadržao fiskalne politike $u$ suverenim okvirima, uz pretežno preventivni karakter. S obzirom na potrebu za kolektivnom disciplinom, Pakt za stabilnost i rast nije nametao disciplinu uz odricanje od suverenosti, nego je svoje okvire zadržao na nivou koordinacije, koristeći dve vrste mera. Preventivna mera podrazumeva jačanje nadzora nad budžetskim pozicijama i koordinacijom ekonomskih politika, a odvraćajuće mere podrazumevaju definisanje postupka u slučaju prekomernog deficita. Eskalacija Globalne recesije i kršenje reformisanog Pakta za stabilnost i rast, uslovilo je uvođenje novih mehanizama upravljanja, sa fokusom na mehanizmima finansijske stabilizacije u zemljama sa fiskalnim problemima. Mehanizmi bi se pokretali samo uz stroga pravila i ukoliko bi Evrozona bila ugrožena, i predstavljaju širi okvir delovanja, uključujući fiskalnu sferu u značajnoj meri. Prvo, obrazovan je Evropski semestar (2010), kao deo mehanizma upravljanja i koordinacije fiskalnih politika u EU. Zatim, osnovan je privremeni Evropski mehanizam za finansijsku stabilnost (European Financial Stabilisation Mechanism - EFSM), kao i Evropski fond za finansijsku stabilnost, koji je privatni subjekat (European Financial Stability Facilities - EFSF). U 2012, osnovan je Evropski stabilizacioni mehanizam (European Stability Mechanism - ESM), definisan međunarodnim sporazumom između članica Evrozone, sa ukupnim kapacitetom finansiranja od 700 milijardi evra. ESM ima za cilj da pruži ekonomijama preventivnu pomoć, da dodali zajmove, da kupuje obveznice članica Evrozone na primarnom i sekundarnom tržištu, da pruža kredite Vladama, da vrži dokapitalizaciju. Navedeni mehanizmi spasavanja (bail-out), podržali su ekonomije koje su, usled fiskalnih kriza, imale otežan pristup međunarodnim tržištima kapitala, ili su u potpunosti izgubile pristup, kao što su Grčka, Portugalija, Irska, Kipar, Śpanija. ESM je, konačno, zamenio prethodno definisana dva programa EFSM i EFSF, pa se novi program spasavanja u Evrozoni sprovodi isključivo preko ESM.

U kontekstu fiskalnih pravila, definisan je čvršći fiskalni okvir putem six-pack i two-pack reforme i, konačno, Fiskalnog sporazuma (2012). Prema Fiskalnom sporazumu, zemlje članice se obavezuju da održavaju budžetsku ravnotežu ili suficit, pri čemu se limit za fiskalni deficit prepisuje prema strukturnom deficitu koji ne sme preći 0,5\% BDP, odnosno, 1\% BDP ukoliko je javni dug ispod $60 \%$ BDP. Ako zemlja ne potpiše Fiskalni sporazum, ne može da prima pomoć na osnovu Evropskog stabilizacionog mehanizma. Dodatno, definisana je inicijativa da se limit za strukturni deficit od 0,5\% BDP uvede u nacionalna zakonodavstva, odnosno, da bude određeno Ustavom (Bova, Kinda, Muthoora \& Toscani, 2015). Većina zemalja je upravo to i učinila, ali neke sa zakašnjenje (Belgija, Grčka), dok su druge uvele ove odredbe, doduše, na zakonodavnom, a ne na Ustavnom nivou kao što je bila preporuka.

Postojeće zakonodavstvo je unapredilo nadzor nad budžetskim politikama zemalja članica, ali se sve više potencira potreba za jačanjem fiskalnog kapaciteta i daljih koraka $\mathrm{u}$ konvergenciji fiskalnih politika zemalja Evrozone, ali i EU. S tim u vezi, javljaju se novi predlozi za razvoj zakonodavnog okvira (Bova, Kinda, Muthoora, \& Toscani, 2015), na čelu sa Evropskom investicionom stabilizacionom funkcijom (European Investment Stabilization Function - EISF). EISF je definisan kao deo finansijske perspektive 2021-2027, sa ciljem uspostavljanja makroekonomske stabilizacije i jačeg odgovora na asimetrične šokove, kao i sprečavanje prelivanja kriza. Dakle, novi okvir 
fiskalnih pravila usmeren je ka stabilizacionoj funkciji (Schaechter, Kinda, Budina \& Weber, 2012), kao i većoj konvergenciju fiskalnih politika zemalja EU.

\section{HLADAN TUŠ VERSUS VIŠEGODIŠNJE EPIZODE U EU PRE GLOBALNE RECESIJE}

Uzimajući u obzir postojeću arhitekturu fiskalnih pravila u EU, kao i prezentovan teorijski okvir kanala putem kojih dolazi do efekata fiskalne konsolidacije, empirijski su analizirane epizode fiskalne konsolidacije u ekonomijama EU, u periodu pre i nakon Globalne recesije.

$\mathrm{Na}$ osnovu dužine trajanja fiskalne konsolidacije, postoji jednogodišnje fiskalno prilagođavanje, kada se u nekoj godini budžetski deficit smanji od 1 do $2 \%$ BDP, a često se poistovećuje sa izrazom fiskalni šok ili hladan tuš (cold shower). Objašnjenje za ovakvu definiciju je da promena budžetskog deficita u takvoj razmeri ne može biti posledica uobičajenog kretanja u ekonomiji, nego se ovaj vanredni rezultat povezuje automatski sa merama fiskalne politike. Konkretno, u radu A. Alesina i S. Ardanga (2009), jednogodišnji period fiskalne konsolidacije se smatra onim u kom je prirast u ciklično prilagođenoj primarnoj budžetskoj ravnoteži najmanje 1,5\% BDP. Fiskalna konsolidacija se smatra uspešnom ukoliko je došlo do kumulativnog smanjenja udela javnog duga u BDP za iznos veći od 4,5\% BDP, tri godine posle uvođenja mera fiskalnog prilagođavanja. Efekti fiskalne konsolidacije se smatraju ekspanzivnim ukoliko je prosečan privredni rast $\mathrm{u}$ periodu sprovođenja mera i dve godine nakon toga veći od vrednosti $75 \%$ ranga privrednog rasta tokom svih epizoda fiskalnog prilagođavanja. Navedena dva kriterijuma su povezana, jer fiskalno prilagođavanje uz brži privredni rast znači veću verovatnoću da će efekti fiskalne konsolidacije biti ekspanzivni, a posledično i uspešni. Dakle, hladan tuš podrazumeva relativno velike promene preduzete u kratkom vremenskom periodu, za razliku od gradualnih promena, koje su manje, ali preduzete $\mathrm{u}$ dužem vremenskom periodu. Konkretno, jedna višegodišnja epizoda fiskalne konsolidacije, prema A. Alesina-i i S. Ardanga-u (2015) je:
- period od 2 godine, u kojima se ukupno poboljšava pozicija ciklično prilagođenog primarnog budžetskog deficita za $2 \%$ BDP, kao i da postoji poboljšanje u obe godine posebno;

- period od 3 godine, u kojima se ukupno poboljšava pozicija ciklično prilagođenog primarnog deficita za 3\% BDP, kao i da postoji poboljšanje u sve tri godine posebno.

Kada je reč o višegodišnjim epizodama, fiskalna konsolidacija se smatra uspešnom ukoliko je udeo javnog duga u BDP niži dve godine nakon epizode fiskalne konsolidacije, $\mathrm{u}$ odnosu na njegovu vrednost poslednje godine epizode. Fiskalna konsolidacija je ekspanzivna ukoliko je rast BDP tokom perioda fiskalnog prilagođavanja veći u odnosu na period pre epizode.

Jednogodišnje fiskalne konsolidacije - hladan tuš, zabeležene su u većini ekonomija EU u analiziranom periodu pre Globalne recesije, od 1990. do 2007. Komparativni pregled fiskalnih konsolidacija prikazan je u Tabeli 1, koristeći alternativne metode:

- ex-post, na osnovu promena u ciklično prilagođenom primarnom budžetskom deficitu, obrađen u radu M. Larch i A. Turrini (2008) i u radu A. Alesina i S. Ardanga (2015), i

- narativni metod, primenjen u radu P. Devries, J. Guajardo, D. Leigh i A. Pescaroti (2011).

Oba metoda prepoznaju hladan tuš u određenim godinama, osim u slučaju Bugarske (koja stoga nije prikazana u Tabeli 1), dok za Grčku relevantni podaci za ceo period nisu dostupni. Dinamizam sprovođenja epizoda fiskalnog prilagođavanja, kao i njihova uspešnost se razlikuje $\mathrm{u}$ analiziranom vremenskom periodu. U prvoj analiziranoj dekadi, u periodu 19902000, u ekonomija EU je implementirano čak 100 jednogodišnjih epizoda fiskalnog prilagođavanja. Međutim, njihova uspešnost je bila veća u periodu 1995-2000, u odnosu na period 1990-1995, kao posledica definisanog fiskalnog okvira na nivou EU i procesa konvergencije u okviru EMU. Period 20002007, karakteriše zamor od fiskalnih konsolidacija, koji se reflektuje u smanjenom broju implementiranih 
Tabela 1 Godišnja fiskalna prilagođavanja (hladan tuš) i višegodišnje epizode fiskalne konsolidacije u EU-28, do Globalne recesije

\begin{tabular}{|c|c|c|c|c|c|c|c|c|c|c|c|c|c|c|c|c|c|c|c|}
\hline & \multicolumn{18}{|c|}{ Hladan tuš } & \multirow{2}{*}{$\begin{array}{l}\text { Višegod. } \\
\text { Episode } \\
\text { 1990-2007 }\end{array}$} \\
\hline & 음 & হু & ๙ั & হू & よ̆ & ๙ू & 음 & बू & ๙ & 욤 & 오 & চ্口 & ণ & $\begin{array}{l}m \\
\text { ㅇํํ }\end{array}$ & ఫ্ & $\begin{array}{l}\stackrel{ }{\circ} \\
\stackrel{ }{\circ}\end{array}$ & ○ & 옹 & \\
\hline AT & & & & & & & + & + & & & & + & + & & & & & & $96-97$ \\
\hline $\mathrm{BE}$ & + & & & + & + & + & + & + & + & + & + & + & & & & & + & & $96-98$ \\
\hline $\begin{array}{l}C Y \\
C Z\end{array}$ & & & & & & & & & & & + & & & & $\begin{array}{l}+ \\
+\end{array}$ & + & & & \\
\hline $\mathrm{DE}$ & & + & + & + & + & + & + & + & + & + & + & & & + & + & + & + & + & $\begin{array}{l}92-94 \\
96-00 \\
03-07\end{array}$ \\
\hline DK & & & & & & + & & & & & & & & & + & + & & & $03-05$ \\
\hline $\mathrm{EE}$ & & & 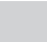 & & & & & & & & + & & & + & & & & & \\
\hline ES & + & & + & + & + & + & + & + & & & & & & & & & & & $94-97$ \\
\hline $\mathrm{FR}$ & & & + & + & + & + & + & + & + & & & & & & & & & & $\begin{array}{l}94-01 \\
04-06\end{array}$ \\
\hline $\mathrm{FI}$ & + & + & & & + & + & + & + & + & + & + & & & & & & & & $\begin{array}{l}93-94 \\
96-98\end{array}$ \\
\hline GB & & & & & + & + & + & + & + & + & + & & & & & & & & \\
\hline HU & & & & & & & & & & + & & & & + & & & & & \\
\hline IT & + & + & + & + & + & + & + & + & + & . & & & & & + & + & + & + & $\begin{array}{l}95-97 \\
06-07\end{array}$ \\
\hline $\mathrm{IE}$ & & & & & & & + & + & + & & & & & & + & & & & $\begin{array}{l}91-94 \\
96-98\end{array}$ \\
\hline LV & & & & & & & + & & & & + & & & & & & & & $03-05$ \\
\hline $\mathrm{LT}$ & & & & & & & & & + & + & & & & & & & & & \\
\hline LU & & & & + & & & & + & & & & & & & & & & & $94-96$ \\
\hline MT & & & & & & & & & & + & & & & & + & + & & & 00-02 \\
\hline $\mathrm{NL}$ & & + & + & + & & & + & + & + & + & + & & & & + & + & 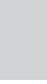 & & $\begin{array}{l}96-00 \\
04-05\end{array}$ \\
\hline PL & & & & & & & & & & & & & & & & + & & & \\
\hline PT & & & + & & + & + & & & & & + & & + & + & & + & + & + & $\begin{array}{l}94-95 \\
02-03 \\
06-07\end{array}$ \\
\hline RO & & & & & & & & + & + & + & & & & & & & & & \\
\hline SE & & & & + & + & + & + & + & + & & & & & & + & + & & & $\begin{array}{l}93-98 \\
03-05\end{array}$ \\
\hline SI & & & & & & & & & & & & & + & & & & & & \\
\hline SK & & & & & & & & & + & & & + & & + & & & & & \\
\hline UK & & & & & & & + & + & + & & + & & & & & & & & $94-00$ \\
\hline & 응 & হু & รั & হू & よ̆ & ๙ू & ڤ̆ & ন & ๙ & ๙ু & 음 & ঠ & $\begin{array}{l}\text { ㅇ } \\
\text { 온 }\end{array}$ & $\begin{array}{l}m \\
\text { O̊ }\end{array}$ & ষ্ণ & $\begin{array}{l}\stackrel{ }{\circ} \\
\stackrel{ }{N}\end{array}$ & 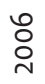 & 옹 & \\
\hline
\end{tabular}

+ Označava godišnja i višegodišnja fiskalna prilagođavanja, koja su utvrđena u radovima Larch i Turrini, 2008; Alesina i Ardanga, 2010; Devries, Guajardo, Leigh i Pescaroti, 2011

Izvor: Autori 
hladnih tuševa u zemljama EU (36 jednogodišnjih epizoda), čija je uspešnost u većini slučaja bila upitna. Navedeno se može pripisati usporavanju privredne aktivnosti i recesiji, koja se ispostavila da je duža i dublja nego što se moglo očekivati, pa su i efekti fiskalnih konsolidacija bili pod udarom ponavljajućih negativnih stopa rasta.

Analizirajući sve godine u kojima je sprovedena fiskalna konsolidacija u EU ekonomijama do Globalne recesije, ispostavlja se da je hladan tuš češće implementiran $\mathrm{u}$ odnosu na višegodišnju fiskalnu konsolidaciju. U 70\% jednogodišnjih fiskalnih konsolidacija, zabeležen je prirast GDP-a za više od 1,5\%, upućujući na ekspanzivnost mera, dok je među ekonomijama EU u razvoju i usponu 30\% fiskalnih konsolidacija zasnovanih na hladnom tušu, rezultiralo rastom od više od 3\% BDP-a (Larch \& Turrini, 2008). Naime, u pretpristupnom i pristupnom periodu, nove ekonomije EU su imale značajne i povoljne rezultate sprovedenih mera fiskalne konsolidacije.

Pored identifikacije višegodišnjih epizoda fiskalnih konsolidacija, od interesa je utvrditi njihovu uspešnost u kontekstu smanjenja ciklično prilagođenog primarnog budžetskog deficita, kao i ekspanzivnost nasuprot kontrakcionim efektima fiskalnih konsolidacija. Iako postoji pretpostavka u ekonomskoj teoriji u smislu očekivanja kontrakcionih efekata u slučaju smanjenja javne potrošnje ili povećanja poreza pri sprovođenju fiskalne konsolidacije, $\mathrm{u}$ radu A. Alesina i S. Ardanga (2015) je pokazano da su češće fiskalne konsolidacije neuspešne nego što imaju kontrakcione efekte. Dakle, češći je problem nemogućnost smanjenja ciklično prilagođenog budžetskog deficita, nego što mere konsolidacije dovode do kontrakcija BDP-a (Slika 1).

Slika 1 pokazuje da samo dve višegodišnje epizode fiskalne konsolidacije, u Nemačkoj 1996-2000. i u Portugaliji 2002-2003, mogu biti okarakterisane kao neuspešne i kontrakcione. Sve ostale identifikovane epizode su rezultirale ekspanzivnim efektima, čime je empirijski potvrđeno postojanje ne-Kejnzijanskih efekata, kao i prva istraživačka hipoteza. Dodatno, rezultati empirijskih analiza ukazuju da su mere fiskalnog prilagođavanja, zasnovane na smanjenju javne potrošnje, češće povezane sa ekspanzivnim efektima, i sa uspehom u smanjenju javnog duga

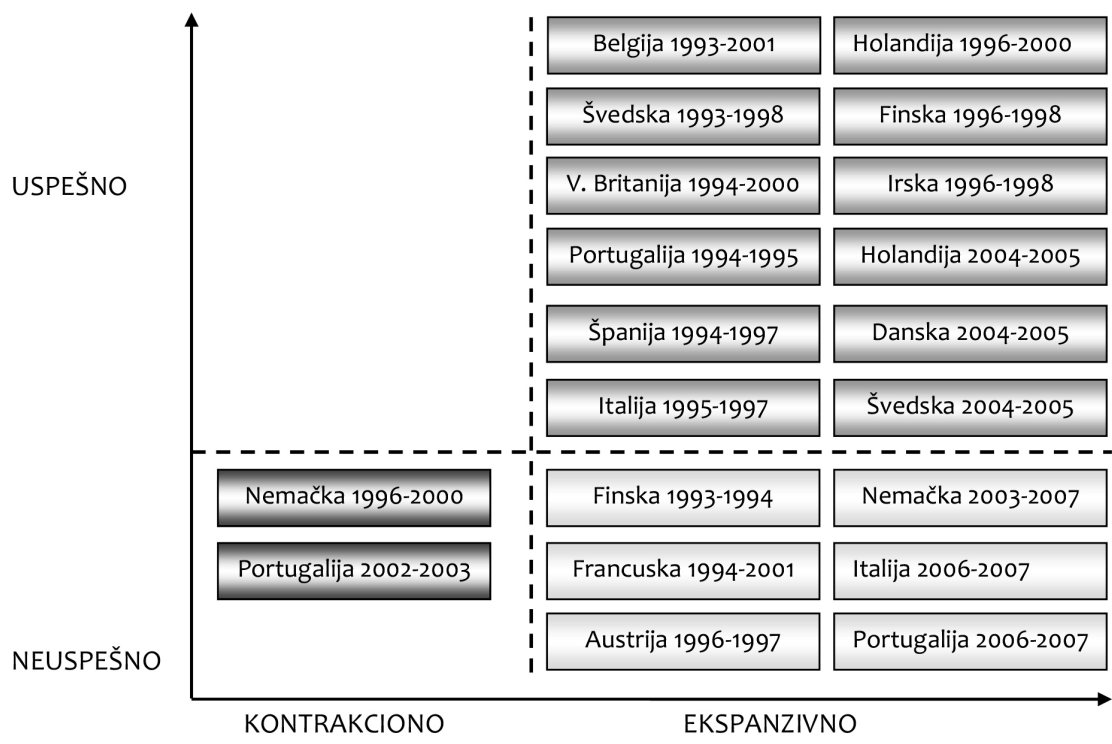

Slika 1 (Ne)uspešne i kontrakcione/ekspanzivne epizode fiskalnog prilagođavanja

Izvor: Autori, na osnovu Alesina i Ardagna, 2010. 
i budžetskog deficita, nego one mere moje su zasnovane na smanjenju poreza. $S$ druge strane, među najuspešnijim višegodišnjim epizodama fiskalne konsolidacije treba izdvojiti Švedsku, u periodu 19931998, kada je fiskalnom konsolidacijom umanjen ciklično prilagođeni budžetski deficit za 14\%, Veliku Britaniju u periodu 1994-2000, kada je umanjenje iznosilo 11\% i Holandiju u periodu 1996-2000, sa topljenjem ciklično prilagođenog budžetskog deficita u iznosu od 8,8\%.

\section{FISKALNA KONSOLIDACIJA POSLE GLOBALNE RECESIJE}

Nakon Globalne recesije, ekonomije EU su počele da sprovode kompleksne reforme na području fiskalne politike, koje nisu obuhvatale samo fiskalnu konsolidaciju u ekonomijama sa prekomernim budžetskim deficitom. Naime, neke zemlje su ušle u proceduru prekomernog deficita (Excessive Deficit Procedure - EDP), a realizovani su i programi podrške. Ulaskom u EDP proceduru, Evropska Komisija je preuzimala nadgledanje javnih finansija u ekonomijama, pri čemu je Velika Britanija ušla 2008, a Španija, Grčka, Irska, Francuska, Nemačka, Italija, Portugalija, Holandija, Belgija i Austrija 2009. Međutim, i dalje su najugroženije bile zemlje periferije koje su već imale oslabljene javne finansije, a čije je probleme Globalna recesija intenzivirala (javni dug u odnosu na BDP u Italiji je u 2008. iznosio $106 \%$, dok je Grčkoj dostigao vrednost od $100 \%$ ). U tim zemljama su implementirani programi podrške, sa ciljem smanjenja budžetskog deficita i javnog duga, ali i jačanje bankarskog sektora i obezbeđenje privrednog rasta. Konačno, ideja je bila da se ponovo zadobije poverenje investitora. Dobijanje finansijske pomoći je određeno veličinom fiskalne krize konkretne ekonomije i potencijalne opasnosti po Evrozonu, a podrazumeva da Vlade moraju potpisati Memorandum o razumevanju (Memorandum of Understanding - MoU), kao i Fiskalni sporazum, kako bi se obezbedila konsolidacija javnih finansija. Definisano je pet različitih programa za spasavanje, a koji od njih je realizovan, zavisilo je od odluke Trojke.
Evropski mehanizam za finansijsku stabilnost (EFSM) je finansiran zaduživanjem Evropske Komisije na međunarodnim finansijskim tržištima, pri čemu je garancija bila sam budžet EU. U Tabeli 2, prikazani su realizovani program finansijske stabilizacije. U periodu 2011-2014, 22,5 milijarde evra je pruženo Irskoj, a 24,3 milijarde evra Portugaliji, dok je 2015, Grčkoj odobren kratkoročni kredit u iznosu od 7,16 milijardi evra. Iz programa EFSF, u periodu 2011-2013, isplaćeno je 17,7 milijardi evra, sa periodom otplate 2029-2042, dok je Portugaliji, u periodu 2011-2014, isplaćeno 26 milijardi evra sa periodom otplate 20252040, dok je Grčka primila 141,8 milijarde evra iz EFSF, u periodu 2012-2015, (izvor podataka je ESM). Pregled realizovanih programa, pod okriljem EFSF, EFSM i ESM, prikazan je u Tabeli 2. Pored navedenih zemalja, indirektno je pomoć dobila i Italija, čije su obveznice otkupljivane od strane Evropske centralne banke $\mathrm{u}$ iznosu od 102,8 milijardi evra. Slično, u slučaju Irske, ECB je otkupila 14,2 milijarde evra, u Grčkoj 33,9, u Španiji 44,3 i Portugaliji 22,8 milijardi evra. Ispostavlja se da su primenjeni hitni programi podrške doprineli oporavku ekonomija i preventivno delovali na sprečavanje prerastanja duboke recesije u depresiju.

Tabela 2 prikazuje dubinu budžetskog deficita pre i posle sprovođenja programa finansijske stabilizacije. Međutim, navedeno poboljšanje nije samo posledica značajne finansijske pomoći, nego i sprovedenih fiskalnih konsolidacija u ekonomijama EU. Permanentne epizode fiskalnih konsolidacija su sprovođene $u$ većini ekonomija EU, a pogotovo su bile neophodne $\mathrm{u}$ krhkim zemljama, sa visokim budžetskim deficitom i javnim dugom pre perioda recesije - pretežno ekonomije periferije EU (Janković, 2019). Međutim, neophodnost fiskalne konsolidacije se ispoljila i u starim članicama EU, pa je, tako, prva višegodišnja epizoda fiskalne konsolidacije nakon Globalne recesije trajala u periodu 2010-2013, a druga u periodu 2014-2015, u Austriji, Danskoj, Nemačkoj, Irskoj, Italiji, Portugaliji, Španiji, Velikoj Britaniji. S druge strane, Finska, Holandija i Švedska su implementirale jednu višegodišnju fiskalnu konsolidaciju u periodu 2010-2015. Time je potvrđena hipoteza da postoje razlike u dužini trajanja, strukturi i efektima fiskalnih konsolidacija, pre i nakon Globalne recesije. 
Tabela 2 Realizovani programi finansijske stabilizacije

\begin{tabular}{|c|c|c|c|c|c|}
\hline & $\begin{array}{l}\text { Izvor } \\
\text { finansi- } \\
\text { ranja }\end{array}$ & Trajanje & Iznos & $\begin{array}{l}\text { Budžet } \\
\text { pre }\end{array}$ & $\begin{array}{l}\text { Budžet } \\
\text { posle }\end{array}$ \\
\hline Grčka & $\begin{array}{l}\text { EFSF, } \\
\text { EFSM, } \\
\text { ESM, } \\
\text { MMF }\end{array}$ & $\begin{array}{l}2011- \\
2019 .\end{array}$ & $\begin{array}{l}256 \\
\text { milijardi } \\
\text { evra }\end{array}$ & $\begin{array}{l}-15.1 \% \\
\text { BDP u } \\
2009 .\end{array}$ & $\begin{array}{l}1,1 \% \text { BDP } \\
u 2018 .\end{array}$ \\
\hline Portugalija & $\begin{array}{l}\text { EFSF, } \\
\text { EFSM, } \\
\text { MMF }\end{array}$ & $\begin{array}{l}2011- \\
2014 .\end{array}$ & $\begin{array}{l}78 \\
\text { milijardi } \\
\text { evra }\end{array}$ & $\begin{array}{l}-11.2 \% \\
\text { BDP u } \\
2010 .\end{array}$ & $\begin{array}{l}0,5 \% \\
\text { BDP u } \\
2018 .\end{array}$ \\
\hline Irska & $\begin{array}{l}\text { EFSF, } \\
\text { EFSM }\end{array}$ & $\begin{array}{l}2010- \\
2013 .\end{array}$ & $\begin{array}{l}85 \\
\text { milijardi } \\
\text { evra }\end{array}$ & $\begin{array}{l}-32.1 \% \\
\text { BDP u } \\
2010 .\end{array}$ & $\begin{array}{l}\text { 0\% BDP } \\
\text { u } 2018 .\end{array}$ \\
\hline Španija & ESM & $\begin{array}{l}2012- \\
2013 .\end{array}$ & $\begin{array}{l}41,3 \\
\text { milijardi } \\
\text { evra }\end{array}$ & $\begin{array}{l}-11 \% \\
\text { BDP u } \\
2009 .\end{array}$ & $\begin{array}{l}-2,5 \% \\
\text { BDP u } \\
2018 .\end{array}$ \\
\hline Kipar & $\begin{array}{l}\text { ESM, } \\
\text { MMF }\end{array}$ & $\begin{array}{l}2012- \\
2016 .\end{array}$ & $\begin{array}{l}10 \\
\text { milijardi } \\
\text { evra }\end{array}$ & $\begin{array}{l}-9 \% \\
\text { BDP u } \\
2014 .\end{array}$ & $\begin{array}{l}-4,8 \% \\
\text { BDP u } \\
2018 .\end{array}$ \\
\hline
\end{tabular}

Izvor: Autori

Efekti implementiranih fiskalnih konsolidacija nakon Globalne recesije se reflektuju kroz umanjenje vrednosti tekućih varijabli (ciklično prilagođenog budžetskog deficita). Međutim, manje su se pokazale uspešnim pri redukciji stok varijabli (akumuliranog javnog duga). Naime, prema B. Pierluigi-ju i D. Sondermann-u (2018), u prvoj dekadi EMU makroekonomske neravnoteže $u$ tekućim varijablama su korigovane $\mathrm{u}$ značajnom stepenu, dok su makroekonomske neravnoteže u stok varijablama ostale. Stoga, noviji mehanizmi upravljanja, jačanje fiskalnog okvira uspostavljanjem čvršćih supranacionalnih fiskalnih pravila sa njihovom primenom $\mathrm{u}$ nacionalnim zakonodavstvima postaje od izuzetne važnosti (Debrun, Moulin, Turrini, Ayuso-i-Casals \& Kumar, 2008).

\section{ZAKLJUČAK}

Globalna recesija je naglasila sve mane nedovršenog projekta Evropske unije, jer uz jedinstvenu monetarnu politiku, heterogena fiskalna politika se nije pokazala sposobnom da apsorbuje asimetrične šokove koji su se u kriznim uslovima generisali, uprkos fleksibilnosti nacionalnih fiskalnih politika. Stoga se u radu kompariraju epizode fiskalnog prilagođavanja u 28 ekonomija EU, u periodu pre i nakon recesije (19902007. i 2010-2015, respektivno), uzimajući u obzir dužinu trajanja fiskalne konsolidacije (hladan tuš versus višegodišnje epizode), kao i efekte primenjenih fiskalnih konsolidacija (uspešnost/neuspešnost $u$ smanjenju/rastu ciklično prilagođenog primarnog budžetskog deficita i ekspanzivni/kontrakcioni efekti u kontekstu rasta/pada BDP-a).

Dinamizam sprovođenja epizoda fiskalnog prilagođavanja, kao i njihova uspešnost se razlikuje $\mathrm{u}$ analiziranom vremenskom periodu. Postavljena istraživačka hipoteza je potvrđena ukazujući da postoje uspešni i ekspanzivni efekti hladnog tuša i graduelnih epizoda fiskalne konsolidacije pre i nakon Globalne recesije. U pre-recesionom periodu, broj implementiranih jednogodišnjih epizoda je veći $\mathrm{u}$ odnosu na post-recesioni period, kada su pretežno implementirane višegodišnje epizode fiskalnih konsolidacija. Generalno je uspešnost hladnog tuša zabeležena u $70 \%$ realizovanih fiskalnih konsolidacija, dok se posebno izdvajaju fiskalne konsolidacije ekonomija EU u razvoju i usponu. $U$ vezi sa potencijalnom ekspanzivnošću fiskalnih konsolidacijama, podaci ukazuju da su samo dve višegodišnje episode, u Nemačkoj 19962000. i u Portugaliji 2002-2003, okarakterisane kao neuspešne i kontrakcione. Sve ostale identifikovane epizode su rezultirale ekspanzivnim efektima, čime je empirijski potvrđeno postojanje ne-Kejnzijanskih efekata. Implikacije empirijskih analiza, koje kreatori ekonomskih politika trebaju sagledati, ukazuju da su mere fiskalnog prilagođavanja zasnovane na smanjenju javne potrošnje češće povezane sa ekspanzivnim efektima, i sa uspehom u smanjenju javnog duga i budžetskog deficita, nego one mere koje su zasnovane na smanjenju poreza.

Nakon Globalne recesije, ekonomije EU su počele da sprovode kompleksne reforme na području fiskalne politike, koje nisu obuhvatale samo fiskalnu konsolidaciju u ekonomijama sa prekomernim budžetskim deficitom. Neke zemlje su ušle u EDP 
proceduru, a neke su bile deo realizovanih programa podrške u kontekstu Evropskih stabilizacionih mehanizama. Permanentne epizode fiskalnih konsolidacija su sprovođene u većini ekonomija EU, počevši od 2010, a pogotovo su bile neophodne u krhkim zemljama sa visokim budžetskim deficitom i javnim dugom pre perioda recesije. Stoga se ispostavlja da je jačanje fiskalnog okvira, uspostavljanjem komplementarnosti između supranacionalnih i nacionalnih fiskalnih aranžmana u post-recesionom period, od izuzetne važnosti.

Iako istraživanje pruža odgovore o efektima implementiranih fiskalnih konsolidacija nakon Globalne recesije, koje se reflektuje kroz smanjenje vrednosti ciklično prilagođenog primarnog budžetskog deficita (tekuće varijable), ostaje otvoreno pitanje koliko su se mere fiskalne konsolidacije pokazale uspešnim pri redukciji akumuliranog javnog duga (stok varijable). Stoga bi buduća istraživanja trebala biti usmerena ka multikointegracionoj analizi u okviru modela panela, koja bi pri analizi efekata fiskalnih konsolidacija obuhvatila vezu između varijabli toka i stoka u ekonomija EU.

\section{REFERENCE}

Alesina, A., \& Perotti, R. (1998). Fiscal adjustments in OECD countries: Composition and macroeconomic effects. IMF Staff Papers, 44(2), 210-248. doi.org/10.2307/3867543

Alesina, A., \& Ardanga, S. (1998). Tales of fiscal adjustment. Economic Policy, 13(27), 487-545. doi.org/10.1111/14680327.00039

Alesina, A., Ardagna, S., Perotti, R., \& Schiantarelli, F. (2002). Fiscal policy, profits, and investment. American Economic Review, 92(3), 571-589. doi:10.1257/00028280260136255

Alesina, A. (2010, April). Fiscal adjustments: Lessons from recent history. Paper presented at the ECOFIN meeting in Madrid.

Alesina, A., \& Ardagna, S. (2010). Large changes in fiscal policy: Taxes versus spending. Tax policy and the economy, 24, 35-68. doi.org/10.1086/649828

Alesina, A., Barbiero, O., Favero, C., Giavazzi, F., \& Paradisi, M. (2015a). Austerity in 2009-2013. Economic Policy, 30(83), 383-437. doi:10.1093/epolic/eiv006
Alesina, A., Favero, C., \& Giavazzi, F. (2015a). The Output Effects of Fiscal Consolidation Plans. Journal of International Economics, 96(S1), S19-S42. doi.org/10.1016/j. jinteco.2014.11.003

Alesina, A., Azzalini, G., Favero, C., Giavezzi, F., \& Miano, A. (2017). Is it the "How" or the "When" that Matters in Fiscal Adjustments? IMF Economic Review, 66(1), 144-188. doi:10.1057/s41308-017-0047-z

Ardagna, S. (2004). Fiscal Stabilizations: When do they work and why. European Economic Review, 48(5), 1047-1074. doi:10.1016/j.euroecorev.2003.09.010

Barrios, S., Langedijk, S., \& Pench, L. R. (2010). EU fiscal consolidation after crisis: Lessons from past experiences. European Economy - Economic Papers 2008-2015, No 418. doi:10.2765/42879 Beker Pucar, E., \& Glavaski, O. (2019). Monetary stages and frameworks of emerging EU members. Economic Horizons, 21(1), 29-42. doi:10.5937/ ekonhor1901029B

Bova, E., Kinda, T., Muthoora, P., \& Toscani, F. (2015). Fiscal rules at a glance. Working Paper 12/273, International Monetary Fund.

Corsetti, G., Kuester, K., Meier, A., \& Muller, G. J. (2010). Debt consolidation and fiscal stabilization of deep recessions. American Economic Review, 100(2), 41-45. doi:10.1257/ aer.100.2.41

Debrun, X., Moulin, L., Turrini, A., Ayuso-i-Casals, J., \& Kumar, M. S. (2008). Tied to the Mast? The Role of National Fiscal Rules in the European Union. Economic Policy, 23(54), 297-362.

Devries, P., Guajardo, J., Leigh, D., \& Pescaroti, A. (2011). A new action-based dataset on fiscal consolidation. Working Paper WP/11/128, International Monetary Fund.

European Commission. (2007). Public finance in EMU 2007. European Commission.

European Commission. (2018). Proposal for a regulation of the European Parliament and of the Council on the establishment of a European Investment Stabilisation Function. Brussels.

Giavazzi, F., \& Pagano, M. (1990). Can severe fiscal contractions be expansionary? Tales of two small European countries. NBER Macroeconomic Annual 1990, 5, 75-122. doi:10.2307/3585133

Guajardo, J., Leigh, D., \& Pescatori, A. (2011). Expansionary austerity: New international evidence. Working Paper 11/158, International Monetary Fund. 
Janković, M. (2019). Impact of financial structure on economic growth: Example of Serbia, Croatia and Slovenia. Anali Ekonomskog Fakulteta u Subotici, 55(42), 147-162. doi:10.5937/ AnEkSub1942147J

Kumar, M., Leigh, D., \& Plekhanov, A. (2007). Fiscal adjustments: Determinants and macroeconomic consequences. Working Paper No. 07/178, International Monetary Fund.

Larch, M., \& Turrini, A. (2008). Received wisdom and beyond: Lessons from fiscal consolidation in the EU. National Institute Economic Review 217(320), European Commission. doi:10.2139/ssrn.1284378

Maroto, R., \& Mulas-Granados, C. (2007). What makes fiscal policy sustainable? A survival analysis of fiscal consolidation in Europe. Public Choice, 134(3), 147-161. doi:10.1007/s11127-007-9211-8

Pierluigi, B., \& Sondermann, D. (2018). Macroeconomic imbalances in the euro area: Where do we stand? Occasional Paper Series No 211, European Central Bank.
Schaechter, A., Kinda, T., Budina, N., \& Weber, A. (2012). Fiscal rules in response to the crisis - toward the "nextgeneration" rules. A New Dataset. Working Paper, 12/187, International Monetary Fund.

Sutherland, A. (1997). Fiscal crises and aggregate demand: can high public debt reverse the effects of fiscal policy? Journal of Public Economics, 65(2), 147-162. doi.org/10.1016/S00472727(97)00027-3

Tanasić, L. (2019). Comparative overview of transfer pricing tax regulation in the World. Anali Ekonomskog Fakulteta $u$ Subotici, 55(42), 111-127. doi:10.5937/AnEkSub1942111T

Von Hagen, J., Hughes Hallet, A., \& Straush, R. (2002). Budgetary institutions for sustainable fiscal policies. In M. Buti, J. Von Hagen, and C. M. Mongay (Eds.). The Behaviuor of Fiscal Authorities: Stabilization, Growth and Institutions (pp. 94-110). London, UK: Palgrave Macmillan.

Yang, W., Fidrmuc, J., \& Ghosh, S. (2015). Macroeconomic effects of fiscal adjustment: A tale of two approaches. Journal of International Money and Finance, 57, 31-60. doi. org/10.1016/j.jimonfin.2015.05.003

Primljeno 16. februara 2020, nakon revizije, prihvaćeno za publikovanje 13. aprila 2020. Elektronska verzija objavljena 24. aprila 2020.

Olgica Glavaški je docent na Ekonomskom fakultetu u Subotici Univerziteta u Novom Sadu. Doktorirala je na Ekonomskom fakultetu Univerziteta u Beogradu, iz naučne oblasti Ekonomija. Izvodi nastavu iz predmeta Makroekonomija EU, Ekonomija javnog sektora, Makrometrija, Politička ekonomija evropskih integracija, na osnovnim, master i doktorskim akademskim studijama. Ključne oblasti naučnoistraživačkog interesovanja su ekonomske politike, fokus na fiskalnu politiku i održivost javne potrošnje.

Emilija Beker Pucar je vanredni profesor na Ekonomskom fakultetu u Subotici, Univerziteta u Novom Sadu, gde je doktorirala iz naučne oblasti Opšta ekonomska teorija i politika. Izvodi nastavu iz predmeta Međunarodna ekonomija, Međunarodne finansije, Makrometrija, Međunarodna makroekonomija na osnovnim, master i doktorskim akademskim studijama. Ključne oblasti naučnoistraživačkog interesovanja su ekonomske politike, sa fokusom na monetarnu politiku i režime deviznog kursa. 


\title{
FISCAL CONSOLIDATION IN THE EU-28: MULTIYEAR VERSUS COLD-SHOWER EPISODES
}

\author{
Olgica Glavaski and Emilija Beker Pucar \\ Faculty of Economics in Subotica, University of Novi Sad, The Republic of Serbia
}

\begin{abstract}
In the aftermath of the global recession, the need for fiscal consolidation in order to reduce budget deficits and the public debt has intensified, but with the aim to make the measures applied not affect the further slowdown of the economic activity in the European Union (EU) economies. In this paper, the episodes of the fiscal consolidation in the period from 1990 to 2015 in the 28 EU economies are analyzed, differentiating the multiyear episodes against the one-year (i.e. cold shower) episodes and their effects before and after the global recession. The episodes of the fiscal consolidation that result in successful (a reduction in the cyclically-adjusted primary budget deficit) and expansionary effects (the GDP growth) are identified, thus empirically confirming the existence of non-Keynesian effects. The stated affirms the idea that the achievement of fiscal sustainability by using austerity measures does not necessarily imply contractions in economies and that the development of a fiscal architecture in the EU by establishing complementarity between the national and supranational fiscal rules is of extraordinary importance in the post-crisis period.
\end{abstract}

Keywords: fiscal consolidation, EU economies, fiscal rules, non-Keynesian effects

JEL Classification: H30, H62, F15 